\title{
LA DIMENSIÓN POLÍTICA DE BRETÓN DE LOS HERREROS DURANTE LA PRIMERA MITAD DEL SIGLO XIX
}

\author{
A D. Ramón Querol Muller, in memoriam \\ Gracia Gómez Urdáñez*
}

UNAS CONSIDERACIONES PREVIAS SOBRE HISTORIA Y BIOGRAFÍA

Tradicionalmente y desde tiempos remotos la biografia ha sido un género cultivado con notable éxito. Basada tanto en las necesidades propagandísticas del poder como en la eterna inclinación del hombre a admirar la trayectoria singular de los personajes históricos, el secreto de su pervivencia a lo largo de la historia no es otro que la armoniosa combinación de las características propias de una fórmula encomiástica y laudatoria. Si bien es cierto que incluso en la actualidad, y después de una profunda renovación historiográfica, todavía subsiste en algunas biografías cierto carácter rancio y en unos pocos biógrafos tentaciones hagiográficas, el género disfruta hoy de una indiscutida categoría avalada por pruebas irrefutables en favor de su validez para el análisis histórico.

Aunque en algunos países europeos, cuyo recorrido historiográfico es suficientemente conocido, la renovación de la biografía tiene una trayectoria más larga, en el caso español y sobre todo para la historia contemporánea, podría afirmarse que hay un principio concreto, una carta fundacional. Se trata, sin duda, de la obra de José Álvarez Junco sobre Lerroux, que inauguró en el año noventa la regeneración de la biografia histórica y desde un principio se convirtió en modelo pionero y referencia básica para los estudios biográficos. ${ }^{1}$. Desde la publicación de El Emperador del Paralelo, la reflexión en torno al uso de la biografia en la actualidad se ha ampliado considerablemente. A la biografía histórica le interesan los datos y también la reconstrucción de una vida, pero como punto de partida. El objetivo a cubrir tiene que ver con preguntas y problemas planteados por el historiador y no exactamente con la exposición indiscriminada de todas y cada una de las noticias y circunstancias -por insignificantes, e incluso, frívolas que sean- sobre el personaje. Por tanto, cuando de biografía histórica se trata no es necesario incluir todos los datos, sino una selección

* Departamento de Historia Moderna y Contemporánea. Universidad de Zaragoza.

1. ÁLVAREZ JUNCO, J., 1990. 
de los mismos en función de la utilidad documental que aportan para poder interpretar aquellos fenómenos históricos previamente propuestos. En definitiva, lo que debe tenerse en cuenta es que en la biografia histórica, el personaje no es el fin, sino el medio ${ }^{2}$.

Lógicamente, este es el espíritu que anima las páginas que siguen. La figura de Manuel Bretón de los Herreros ha tenido distintos tratamientos biográficos, unos meramente aproximativos y otros más ambiciosos; pero la realidad es que el personaje ha sido analizado fundamentalmente desde un punto de vista filológico y literario ${ }^{3}$. Este hecho, que no es de extrañar tratándose de uno de los dramaturgos más prolíficos del siglo romántico, no ha servido, sin embargo, para tener una visión histórica completa de quien hasta el momento ha sido conocido casi exclusivamente por su producción literaria. Quizás permanece oculta por una especialización sobreestimada y una interdisciplinariedad nunca aplicada, pero la personalidad de Bretón de los Herreros tiene una dimensión política inextricablemente unida a su actividad profesional. No podía ser de otra forma si se tiene en cuenta que la literatura, como todas las demás facetas creativas, es en definitiva una manifestación más de la historia, cuyo análisis e interpretación, dicho sea de paso, debe ser prioritariamente histórica. Esa circunstancia, constante a lo largo de la historia y particularmente conspicua en los siglos XVIII y XIX, se puede apreciar con especial nitidez en el caso de la España decimonónica, en la que los nombres de Larra, Espronceda, Escosura, Mesonero Romanos, el Duque de Rivas, Pérez Galdós o Martínez de la Rosa, están vinculados de manera palpable con las ideas y los ambientes políticos. Y es que, en el siglo XIX español, como aseguraba Santos Juliá, no es posible «deslindar nítidamente los campos: se era poeta, periodista y político sin contradicción interior alguna $»^{4}$.

Bretón de los Herreros perteneció a una generación implicada en la promoción de cambios profundos y acostumbrada a tomar partido en constantes movimientos revolucionarios. Una generación que impulsó y dirigió la transformación revolucionaria de su tiempo histórico. En los orígenes de la España contemporánea el liberalismo enroló en sus filas a quienes aspiraban a sustituir el Antiguo Régimen por una nueva estructura política liderada por la burguesía. En la construcción del nuevo Estado se comprometieron abogados, comerciantes, médicos o poetas que, pertenecientes a una clase social en ascenso, fueron por su propia experiencia histórica, hombres esencialmente políticos. Todos aquellos liberales tuvieron, por encima de su dedicación personal, la "profesión" común de contribuir políticamente a la consecución de los cambios y a la materialización de sus principios ideológicos. Los principales biógrafos que se han ocupado de la figura de Bretón han insistido en la indiferencia del escritor por la política y en su desapasionada manera de observarla, pero es un error histórico

2. Esta es fundamentalmente la línea que sigue la tesis doctoral que actualmente realizo sobre la biografia de Salustiano de Olózaga; figura clave en el discurrir político del reinado isabelino. La investigación, que pretende superar los límites de una biografia descriptiva y personal, busca respuestas a problemas más generales que tienen que ver con la formación de las élites en la España decimonónica y con otros fenómenos históricos derivados de la revolución burguesa y la práctica política del liberalismo español.

3. Además de los trabajos menores que le dedicaron sus contemporáneos -que se irán citando a lo largo del texto- en los que se destaca casi exclusivamente la contribución renovadora de Bretón al teatro de la época, también en la mayoría de los estudios actuales prima el análisis literario. Por citar sólo los ejemplos más significativos, véanse las obras de MURO, M. A., 1985 y 1992; o SÁNCHEZ SALAS, B., 1990.

4. JULIÁ, S., 1995: 349. 
pensar que en aquel ambiente se podía ser autor dramático sin ser hombre político. Bretón no destacó, en efecto, por una posición comprometida de forma inamovible con el liberalismo más osado. Hay indicios de su participación en favor del constitucionalismo durante los difíciles años del Trienio Liberal, pero ni mucho menos se implicó en la lucha clandestina contra la restauración absolutista de Fernando VII que, a partir de 1824, impuso la más cruel de las represiones. A pesar de su amistad con Salustiano de Olózaga, líder indiscutible del progresismo y decidido defensor de los principios liberales, tampoco tuvo Bretón una postura política inequívocamente progresista. Y finalmente, en sus muchas obras no son frecuentes las alusiones a los avatares y acontecimientos políticos de su momento histórico. Como veremos más adelante, estas son pruebas, no de desinterés político, sino de un oportunismo calculadamente practicado cuyo origen tiene que ver con la necesidad de supervivencia social en el Madrid elitista de tertulia y salón.

\section{la España de la transición. Del Antiguo Régimen al liberalusmo (1808-1833).}

La crisis del Antiguo Régimen en España, anunciada al menos desde las últimas décadas del siglo XVIII, se agravó de forma irreversible con el estallido de la guerra de la Independencia. Es manifiesto que 1808 marca un antes y un después en la agonía del viejo orden. Pero la fuerza de los primeros golpes revolucionarios no impidió que el absolutismo, aunque cada vez más debilitado y con una desgastada base social, se mantuviera hasta 1833 siquiera oficialmente. Entre la guerra de la Independencia y la muerte de Fernando VII se configura para la historia de España un complejo periodo con revolución y reacción, protagonizado por los últimos defensores de la monarquía absoluta y los primeros adalides decididos del liberalismo.

El estallido de la guerra de 1808 sorprendió al joven Bretón de los Herreros en Madrid cuando contaba apenas 12 años, pues según las noticias aportadas principalmente por su sobrino Cándido Bretón y comprobadas años después por Felipe Abad, Manuel Bretón había nacido en 1796. Como indican algunos de sus biógrafos, en 1806 la familia se trasladó a Madrid, donde parece que buscaba mayor fortuna que la que podía proporcionar el pequeño pueblo de Quel, localizado en la zona más árida de La Rioja y comparativamente, también de las menos dinámicas desde un punto de vista económico. Pero la interpretación de aquella emigración por causa de la penuria económica, si bien parece lógica, no está en modo alguno documentada, e incluso podría ponerse muy en cuestión si atendemos al estudio que realizó Felipe Abad basándose en el Catastro de Ensenada. Según este autor, en 1752 la ascendencia paterna de Bretón poseía un patrimonio modesto, pero las tierras, el ganado y los bienes inmuebles por parte materna eran de proporciones considerables. ${ }^{6}$.Además, y lo que es más importante, la rama familiar paterna era hidalga desde tiempo remoto y parece que la materna logró el reconocimiento de su hidalguía en la Chancillería de Valladolid, lo que significa, entre otras cosas, que tenía dinero, porque es de sobras conocido que litigar pleitos de hidalguía podía costar una buena suma?. La importancia de estos

5. Véanse respectivamente BRETÓN Y OROZCO, C., 1883: III; y ABAD LEÓN, F, 1977: 75-76.

6. ABAD LEÓN, F, 1977:85-95

7. La información sobre la hidalguía de la familia Bretón puede verse en el artículo citado de Felipe Abad. Pero la noticia concreta sobre la Chancillería procede de Eduardo Barriobero, quien según Bernardo 
datos, sencillamente mencionados cuando no relegados en la mayoría de los estudios sobre Bretón, es sin embargo clave. Se conoce la abundancia de hidalgos bien miserables, pero la hidalguía seguía teniendo su importancia, tanto en la España de las últimas décadas del XVIII como poco después en el seno mismo de la revolución liberal. La burguesía dirigente no sólo no prescindió de los antiguos privilegiados, sino que lideró la marcha de los profundos cambios de común acuerdo con la vieja clase terrateniente. La revolución burguesa en España fue, como afirmaba Fontana en una de las frases más recordadas por la historiografia, «una alianza entre la burguesía liberal y la aristocracia latifundista ${ }^{8}$.

Por lo menos desde 1750 , un cúmulo de factores históricos de distinto signo produjeron una transformación progresiva en el seno de la estructura antiguorregimental que fue introduciendo en su funcionamiento económico prácticas incipientemente capitalistas. A finales del siglo ilustrado, aristócratas y nobles se habían acostumbrado a la circulación del dinero líquido y la aspiración de la burguesía emergente era imitar los usos sociales de los privilegiados. Esta mezcla, cada vez más espesa cuanto más se aproximaba el cambio de siglo, es la causa fundamental que explica, en definitiva, el carácter de la revolución burguesa en España. El liberalismo no pretendió, como demuestran los hechos históricos, deshacerse de la nobleza, sino integrarla e incluso forzar su participación en la construcción del nuevo Estado burgués. En plena era liberal, la investidura de nobleza seguía siendo, por tanto, una cédula de probidad. Así pues, el pasado hidalgo de Bretón de los Herreros no era una mala carta de presentación en la nueva sociedad, a pesar de que la literatura política de la época, adoptando una pose conveniente a sus intereses, se mostrara combativa con los privilegiados y beligerante con los títulos nobiliarios.

Pero además, tampoco hay en principio ninguna aportación documental que determine la tantas veces mencionada pobreza de Bretón. De los datos recogidos por Felipe Abad se deduce que la familia no debió disfrutar de una posición económica boyante una vez producidos los efectos de las sucesivas particiones patrimoniales con motivo de las herencias, pero ni mucho menos se trataba de pobres. Si tal atribución se debe al propio testimonio del implicado cuando se confesaba hijo de «un hidalgo pobretón", hay razones fundadas para desconfiar. Presumir de humildad y alardear de unos orígenes modestos era una práctica habitual entre los miembros de aquella minoritaria élite dirigente que, con un marcado carácter de clase, pretendió exhibir, sin embargo, alguna virtud redentora para distinguirse, aunque sólo fuera estéticamente, de quienes habían nacido con apellido noble, supuestos enemigos y en realidad sólo adversarios imaginarios. Nótese, sin embargo, que Bretón menciona como seña de identidad su ascendencia hidalga porque lejos de ser un demérito suponía, bien al contrario, la garantía certificada de su pertenencia a la élite como miembro de pleno derecho. La burguesía, ni siquiera en los momentos de mayor radicalización de su discurso, pretendió integrar a las clases humildes en su proyecto político y desde luego no contó precisamente con "pobretones" entre sus filas. No debemos olvidar

Sánchez Salas, se refirió en 1933 en Rioja Industrial a la decadencia de los Bretón, asegurando que "después del pasado esplendor de su linaje, sólo quedaban unos pergaminos refrendados por la Chancillería de Valladolid". Véase SÁNCHEZ SALAS, B., 1990: 12.

8. FONTANA, J., 1983 ( $5^{\mathrm{a}}$ ed.): 162. 
que el fundamento de su reproducción social y la base de su hegemonía fue la aplicación de un sistema censitario, más estudiado en el terreno electoral, pero manifiesto también en otros campos de la actividad político-social como por ejemplo el ingreso en la Milicia Nacional'.

Las razones para explicar la emigración de los Bretón a Madrid no están, por lo tanto, necesariamente vinculadas con una economía familiar menguada. Es más probable que el origen del traslado se relacione con la necesidad de satisfacer las expectativas que se empezaban a forjar en un mundo cambiante en torno a la capital madrileña como principal centro de poder. A Madrid acudieron, como afirmaba David Ringrose «los que tenían posibilidad de beneficiarse del programa de reformas primeramente articulado en el siglo XVIII y finalmente ejecutado a partir de $1833{ }^{10}{ }^{10}$. Es así como recién llegado a Madrid, el futuro dramaturgo ingresó en el colegio de San Antonio Abad regido por los Padres Escolapios, circunstancia que no se corresponde desde luego con los usos propios de familias humildes ${ }^{11}$. Con un ambiente prebélico y en una ciudad sometida al dominio intruso de los franceses, el joven Bretón hubo de vivir una experiencia histórica de no poca trascendencia. El Madrid de principios de siglo, cuando apenas se recuperaba de la hambruna de 1804 que había provocado la muerte de al menos 4.000 personas, se vio envuelto a partir de 1808 en una guerra devastadora que convirtió la ciudad en un escenario de crueldad e intenso dramatismo $^{12}$. En 1811 Bretón quedó huérfano de padre y, poco después, en el año 12, se alistó en el ejército como voluntario. Inició su carrera militar en el Batallón de a caballo de Ávila y, tras varios destinos, en 1817 se le concedió el traslado al Regimiento de Cazadores de Madrid; solicitud que su madre había cursado para procurar el ingreso de Bretón en el mismo cuerpo militar en el que su hermano, Florentino de los Herreros, era capitán ${ }^{13}$. Entre militares pasó Bretón una década, hasta 1822; año en el que se licenció definitivamente. Transcurrió, por lo tanto, su juventud al margen de la represión fernandina que obligó al exilio mayoritario de quienes participaron en las Cortes de Cádiz e impuso el terror entre los simpatizantes de la doctrina liberal. Desde luego no tiene fácil explicación la larga permanencia de Bretón de los Herreros en el ejército. De no pensar en una vocación auténtica, característica que no parece concordar con su personalidad posterior, es posible que la interpretación más coherente esté relacionada con la imposibilidad de encontrar otro medio de vida mejor y más honorable, toda vez que el ejercicio de trabajos impropios de su clase social queda, obviamente, descartado. En cualquier caso, la formación de Bretón de los Herreros estuvo influida por la transmisión de valores patrióticos especialmente enfatizados en

9. Para la cuestión de las elecciones durante el reinado isabelino véanse los trabajos señeros de BURDIEL, I., 1987; y el más reciente de CABALLERO, M., 1994. En cuanto a la Milicia, PÉREZ GARZÓN,J. S., 1978.

10. RINGROSE, D. R., 1986: 322.

11. La información, después repetida por otros biógrafos, la aportó en primer lugar Antonio Gil de Zárate en su semblanza sobre Bretón publicada en PASTOR DÍAZ, N. y F. DE CÁRDENAS, 1842:6.

12. Algunos datos sobre el Madrid de 1808 pueden verse en JULLÁ, S., 1995: 340-343; y de forma más amplia en DUFOUR, G., 1989.

13. Según consta en el expediente conservado en el Archivo General Militar de Segovia, Bretón ingresó voluntariamente en el ejército el 24 de mayo de 1812. Prestó servicio en varios destinos, fue ascendido a cabo primero y obtuvo la licencia absoluta el 8 de marzo de 1822. Además de la información relativa a su historial militar, en el expediente figura la citada petición de su madre. Véanse los documentos 1 y 2 del apéndice. 
los ambientes militares por las circunstancias históricas del momento. Además, el brote de liberalismo que la restauración absolutista no pudo contener, comprendía también al ejército y reclutó en los círculos militares no pocos adeptos ${ }^{14}$. Poco después del regreso de Fernando VII, Mina lideraba el primer pronunciamiento antiabsolutista y en seguida Porlier protagonizó el levantamiento de La Coruña.A la represión, el liberalismo respondió con nuevas tentativas como la Conspiración del Triángulo que se propuso atentar contra el mismo rey, el levantamiento de Lacy en 1817 , el movimiento encabezado por Van Halen al año siguiente en Murcia, la revuelta de Vidal en Valencia y la conspiración de Cádiz en $1819^{15}$.Todos los intentos fueron abortados por las fuerzas reaccionarias, pero lograron el filantrópico propósito de alimentar la fe revolucionaria y aumentar la lista de mártires del liberalismo, posteriormente exhibida con orgullo por los dirigentes del nuevo orden para apelar a los gloriosos precedentes de la lucha contra el absolutismo.

Aunque expuestos básicamente, estos fueron algunos de los acontecimientos históricos que, aderezados por un clamoroso fervor liberal, acompañaron los años de formación de Bretón de los Herreros. Así como otros muchos jóvenes de su generación, también Bretón, imbuido de este exaltado sentimiento liberal, debió celebrar con entusiasmo el triunfo del pronunciamiento de Riego que inauguró la segunda experiencia constitucional del liberalismo español. Según cuenta Gil de Zárate:

"La revolución de 1820 halló al señor Bretón sirviendo todavía en el ejército, y como éste fue el agente principal de ella, mostróse, más que en ninguna parte, en su filas, el entusiamo que aquel suceso inspiraba ${ }^{16}$.

Además, según se deduce del relato de su amigo Gil, el joven Bretón llegó incluso a significarse públicamente en favor del nuevo régimen político:

«No podía menos el joven poeta de participar de este entusiasmo; y así es que ya en la tribuna de las sociedades patrióticas con enérgicas peroraciones, ya en los convites, frecuentes entonces, con improvisaciones que todos celebraban, ya, en fin, en los combates contra los enemigos de las nuevas instituciones, en todas partes mostró su ardiente amor por la libertad, y su ardor por defenderla ${ }^{17}$

Eran, en efecto, tiempos de tertulia y de vigoroso debate político. Salones y cafés empezaron a tener una importancia clave en la difusión del credo liberal. Las que a partir de 1820 se conocerán como Sociedades Patrióticas formaban parte, en realidad, de una larga tradición de intercambio de ideas políticas que, aunque practicada con especial incidencia durante el apogeo de la llustración, venía siendo habitual desde mucho antes entre los miembros cultivados de las clases altas. Las Sociedades

14. Entre los diversos trabajos en los que se puede seguir la evolución ideológica del ejército español, véanse fundamentalmente CHRISTIANSEN, E., 1973; FERNÁNDEZ BASTARRECHE, F, 1978; CARDONA, G., 1983; SECO SERRANO, C., 1984; o CEPEDA GÓMEZ,J., 1990.

15. Todos estos pronunciamientos pueden seguirse en cualquiera de las obras anteriormente citadas. Pero al menos dos de ellos han sido objeto de un estudio más detenido. La organización del Triángulo fue tratada especificamente por RAMOS RODRGGUEZ, M. P., 1970; y el movimiento de Lacy en FONTANA, J., 1983: 243-256. Sobre el intento de Porlier, aportó noticias particularmente interesantes la CONDESA DE MINA, 1977: 2428; y más recientemente se han publicado datos sobre la figura del militar liberal en BARTHELEMY, Rodolfo G., 1995.

16. GIL DE ZÁRATE,A., 1842:9.

17. GIL DE ZÁRATE,A., 1842:9 
Patrióticas fueron en 1820 la vanguardia del liberalismo ${ }^{18}$. Desde sus estrados se divulgaron las ideas más radicales y fueron pronunciados los discursos más exaltados. Como interpretó Alcalá Galiano, uno de los oradores más asiduos en las tertulias políticas, aquellas pasaron pronto de «reunión de individuos sueltos» a «cuerpo deliberante» y se convirtieron en el escenario "preliminar de actos dirigidos a ejercer el poder» ${ }^{19}$. La Fontana de Oro, el café Lorencini o la Sociedad Landaburiana fueron, en

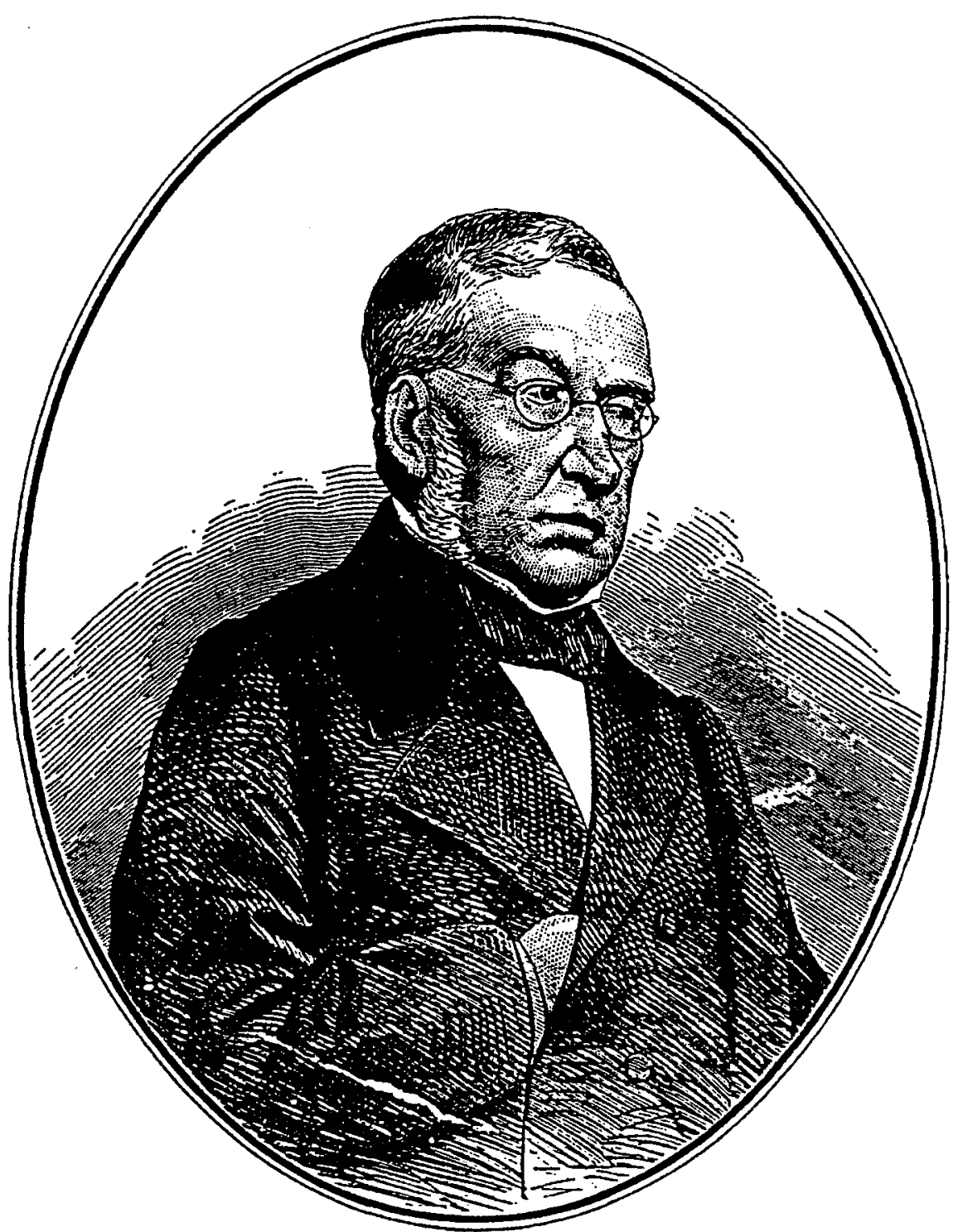

Manuel Bretón de los Herreros

Fuente: La Ilustración Española y Americana, 16-XI-1873, p.689.

18. Sobre los precedentes de las tertulias del XIX, véase LONGARES, J., 1979. Un tratamiento más amplio del tema en GIL NOVALES, A., 1975.

19. Alcalá Galiano se refería principalmente a la Sociedad del café Lorencini que, según su propia visión, era la más extremada y vehemente de todas las que proliferaron en el Madrid del Trienio. Ver ALCALÁ GALIANO, A., 1955: 151. 
efecto, auténticas canteras de liberales para los que el nuevo Estado burgués tenía reservados los principales puestos dirigentes. Bretón de los Herreros vivió la experiencia del Trienio Constitucional integrado, como era lógico, en aquella atmósfera de ebullición política. En 1822 abandonó el ejército y al año siguiente ingresó en el cuerpo de funcionarios de Hacienda desempeñando el puesto de secretario en las Intendencias de Játiva y poco después de Valencia ${ }^{20}$.

Sin embargo, no fue muy duradero su nuevo empleo. La tensión política que los propios partidarios del constitucionalismo habían contribuido a agudizar, alcanzó en 1823 su punto culminante. Aunque Fernando VII se vio obligado a firmar la Constitución en 1820, siguió manejando taimadamente la dirección de los planes contrarrevolucionarios durante los años del Trienio. Y no fue menor la importancia que tuvo en la crisis del periodo constitucional el resultado de la lucha constante entre las distintas facciones liberales, escindidas por primera vez en estos momentos. En efecto, el Trienio, sitiado por un panorama europeo abiertamente hostil a la consolidación del liberalismo que apoyaba la intriga anticonstitucional de Fernando VII, tuvo que enfrentarse además a la división de la filiación liberal. Los retos que planteaba la nueva situación empezaron a dibujar dos sensibilidades políticas que, si bien compartían en esencia un mismo objetivo final, discrepaban en cuanto al uso del método. La fracción doceañista, dirigida principalmente por aquellos liberales del año 12 que sabian de exilio y represión, pensaba, influida por el peso de la experiencia, que esta vez la cautela y la moderación permitirian vencer las resistencias a la restauración constitucional. Mientras, los liberales llamados veintenos y exaltados proponían una vía revolucionaria más incierta, basada en el convencimiento de que moderación y flexibilidad, lejos de aplacar la furia anticonstitucional, servirían muy al contrario para que el enemigo actuara desde dentro con toda impunidad. Unos y otros empezaron muy pronto a manifestar públicamente sus recelos $\mathrm{y}$, cuando apenas había transcurrido un mes de la proclamación del nuevo régimen, los medios de expresión de los exaltados auguraban un desenlace funesto por causa de la mesura, mientras los periódicos de signo moderado reprochaban a los subversivos la obstrucción de la vía posibilista. Las diferencias entre moderados y exaltados acabaron rompiendo la unidad de acción y mermando, en consecuencia, la fuerza revolucionaria ${ }^{21}$. La experiencia liberal se tambaleaba internamente y desde el exterior empezaban a producirse amenazas serias contra el constitucionalismo español ${ }^{22}$. La resolución de intervención del Congreso de Verona fue el respaldo definitivo para que Fernando VII decidiera por fin acabar con los abusos de los constitucionales. Frente a la invasión de los Cien Mil Hijos de San Luis precedidos por el Ejército de la $\mathrm{Fe}$, el liberalismo apenas pudo organizar una resistencia precaria. El gobierno legítimo trasladó las Cortes a Sevilla y, ante el avance de las tropas francesas, fue replegándose hasta Cádiz. Allí nada pudo hacer, sino prolongar su agonía sin más defensa que unos cuantos batallones de la Milicia. Mientras a finales de junio de 1823 el

20. GIL DE ZÁRATE,A., 1842:9.

21. Una sintesis del periodo 1820-1823, puede verse en GIL NOVALES, A., 1989 ( $2^{\mathrm{a}}$ ed.)

22. La situación internacional y su debate sobre la oportunidad de frenar el liberalismo español fue analizado por FONTANA, J., 1987. Desde una perspectiva más concreta que se detiene sobre todo en los intereses en juego por parte de Gran Bretaña, véase el artículo de FUENTES, J. F., 1989. 
potente ejército francés sitiaba la ciudad, emblemático refugio de la Constitución, los liberales empezaban a pensar ya en una nueva expatriación.

Por las noticias que dejó escritas su sobrino Cándido, Bretón vivió los últimos días del régimen liberal en Cartagena ${ }^{23}$. Efectivamente, después de la rendición de Cádiz, todavía resistieron unos días más las plazas de Barcelona, defendida por Espoz y Mina; Cartagena, bajo el mando de Torrijos; y Alicante, donde se había hecho fuerte Chapalangarra ${ }^{24}$. Pero, por fin, a principios de noviembre de 1823 estos tres reductos tuvieron que capitular y los liberales que habían defendido aquellas posiciones se vieron obligados a huit hacia el exilio o a buscar alguna protección en el interior del país. Ante la amenaza de una nueva oleada de persecuciones y represalias, Bretón de los Herreros tuvo que ocultarse y esperar en un refugio seguro el desarrollo de los acontecimientos.

El retorno de Fernando VII al poder supuso la abolición inmediata de la legislación constitucional y sus instituciones. Se restauraron los ayuntamientos de 1820 , se crearon los Voluntarios Realistas para sustituir a la Milicia Nacional y se buscó, en definitiva, anular todos los efectos del constitucionalismo con el fin de restablecer las bases estructurales del Antiguo Régimen. El desmantelamiento expeditivo de la obra liberalizadora del Trienio fue un hecho, pero Fernando VII no se conformó con el fin político de la segunda tentativa constitucional y trató de eliminar hasta el último resto de liberalismo utilizando de forma desproporcionada la represión y el castigo. Quizá porque esta vez la amenaza había sido más seria que en 1812, la venganza absolutista también fue más violenta que en 1814. Los testimonios de quienes vivieron la ominosa década coinciden en presentar la persecución como una despiadada revancha que obligó al liberalismo a sobrevivir en la clandestinidad y en el exilio. La nueva etapa reaccionaria poco tuvo de constructivo, si es que algo podía aún reverdecer sobre el erosionado suelo de una estructura caduca. La agonía del Antiguo Régimen en España luchó por su desesperada supervivencia sólo con las armas de la involución política, el terror y la violencia. Ciertamente los diez años de la restauración fernandina pertenecen, como apuntó Artola, a un «tiempo sin historia» ${ }^{25}$.

Cuando el rey absoluto retomó el control del poder empezaron a ponerse en marcha las primeras operaciones de limpieza. Listas de liberales y normas específicas de depuración política proliferaron por todo el territorio. Según Gil de Zárate, la represión absolutista también alcanzó a Bretón de los Herreros:

«Habiase verificado la reacción de 1823. Bretón se veía despojado de su empleo, de sus esperanzas, comprendido en el número de los proscritos, y vino a Madrid a refugiarse en el seno de su familia» ${ }^{26}$.

Sin embargo, sabemos por Cándido Bretón que no fue exactamente así. Antes de regresar a Madrid, Bretón buscó asilo en Quel, su pueblo natal. En palabras de su sobrino, después de colaborar con la Milicia en Cartagena, el poeta:

"fugose de ella disfrazado con el honroso uniforme militar que durante algunos años había vestido, y el 27 de octubre se presentó al comandante general de Murcia en

23. BRETÓNY OROZCO, C., 1883:VI.

24. Véase al respecto CASTELIS, I., 1989: 12.

25. ARTOLA, M., 1974:51.

26. GIL DE ZÁRATE,A., 1842: 10 . 
calidad de soldado licenciado. Como tal continuó su peregrinación a Quel, y caminando rodeado de peligros sin cuento, y con no pocas fatigas y trabajos, logró llegar sano y salvo al pueblo que le vio nacer, el 29 de noviembre de $1823{ }^{27}$.

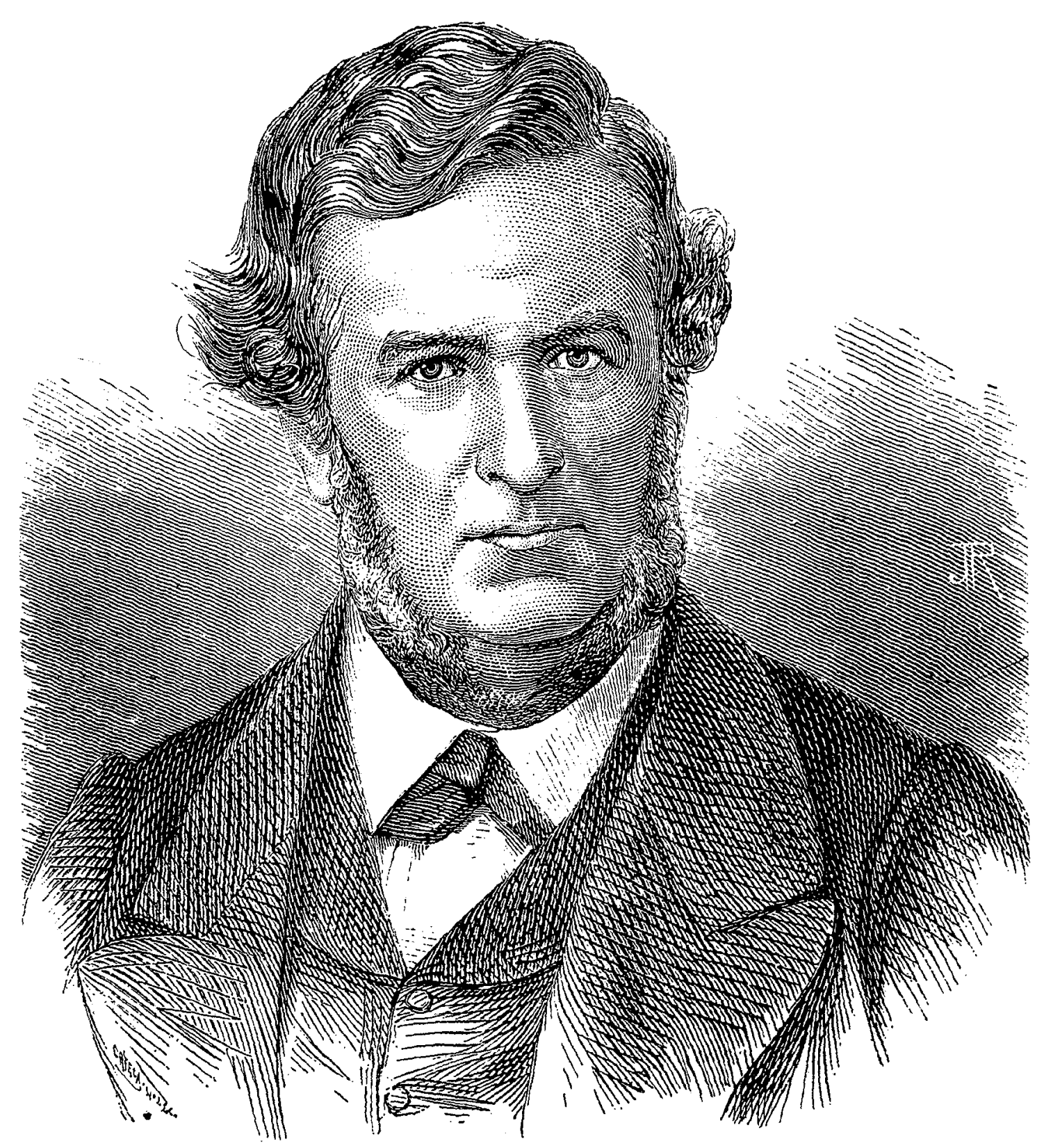

\section{Salustiano Olósaga}

\section{Salustiano de Olózaga}

Fuente:“Galeria de Españoles Thustres. Retratos y Biografias”, El Correo Español, 1893, p. 64.

27. BRETÓNY OROZCO, C., 1883:V. 
Pero Bretón no pensó en Quel por azar. Es que nadie podía volver a Madrid en aquellas circunstancias. Fernando VII había publicado un real decreto por el que se prohibía a los liberales permanecer a menos de cinco leguas del rey durante su viaje de vuelta a Madrid o a quince de la Corte. Quienes habían tomado parte en la defensa del régimen constitucional se vieron obligados, por lo tanto, a buscar un retiro donde, al menos en los primeros momentos, fuera posible permanecer lejos del alcance inmediato de las fuerzas reaccionarias. Muchos liberales partieron hacia el exilio, pero los que se quedaron tuvieron que elegir destinos en pequeños pueblos próximos a su lugar de origen o donde se hubiera instalado alguna rama familiar libre de sospechas en relación con el régimen derrocado. Por citar sólo algún ejemplo, liberales como Salustiano de Olózaga, poco después buen amigo de Bretón, pasó los primeros días de represión en Guadix (Granada) protegido por familiares lejanos cuyo signo político no era favorable a las doctrinas constitucionales. Y Bretón de los Herreros llegó a su pueblo porque era en aquellos momentos un paradero menos arriesgado que la capital.

Pocos días, no obstante, pasó Bretón en su tierra. Quienes han descrito las circunstancias de su situación relacionan siempre su vuelta a Madrid con el peligro que suponía permanecer en lugares pequeños, sin duda más expuesto a ser identificado que en el seno de una gran ciudad ${ }^{28}$. Pero no era esta la única razón. Desde mayo hasta septiembre de 1823, una vez retirado el ejército miliciano de Madrid, una Regencia presidida por el duque del Infantado se había hecho cargo de la situación. La Regencia nombró un gobierno provisional cuya cabeza visible, el canónigo Víctor Damián Sáez, representaba la versión más ultrarreaccionaria del absolutismo. Con el liberalismo derrotado y el retorno de Fernando VII al poder, el gobierno de Sáez fue ratificado por el rey y su principal actividad se centró en practicar un castigo sistemático contra cualquier rastro de liberalismo por mínimo que fuera ${ }^{29}$. Bajo la presidencia de Sáez se vivieron las mayores escenas de crueldad y la ejecución de Riego el 7 de noviembre ha pasado a la historia como el máximo exponente de su desmesurado afán de venganza. Corrían malos tiempos para los liberales, pero muchos de ellos empezaron a regresar a Madrid cuando creyeron poder confiar en que Fernando VII suavizara los correctivos atendiendo a la llamada de la Santa Alianza. Los países que integraban la liga restauradora enseguida pidieron moderación a Fernando VII ante la alarma que despertaban las noticias sobre la represión en España. Luis XVIII trató de influir en la campaña purificadora recomendando al monarca absoluto que tuviera en cuenta los efectos perniciosos de un «despotismo ciego» que «lejos de aumentar el poder de los reyes, lo debilita $[\ldots]$ y los pueblos, inquietos y atormentados, se precipitan en las revoluciones ${ }^{30}$. La insistente presión de la Santa Alianza y los consejos del duque de Angulema, también partidario de introducir ciertas reformas como estrategia para garantizar el mantenimiento del régimen, inclinaron la orientación del absolutismo y Fernando VII admitió la reforma de su gobierno. En diciembre de 1823 Sáez fue destituido y la formación del nuevo gobierno incluyó a algunos reformistas que, si bien su preocupación principal era simular la existencia de cierto aperturismo político de

28. Véanse BRETÓN Y OROZCO, C., 1883:VI; o también LE GENTIL, G., 1909: 18.

29. Sobre la organización política del absolutismo restaurado, los principales datos en ARTOLA, M., 1968; y BALDÓ LACOMBA, M., 1988.

30. Citado en ARTOLA, M., 1968: 846. 
cara a las exigencias de la Santa Alianza, hizo renacer alguna esperanza entre los liberales. En este contexto Bretón de los Herreros volvió a Madrid y aunque en un principio no le debió resultar fácil ocultar su pasado, logró encontrar un resquicio en el nuevo marco político, en el que a la postre pudo ocupar un cómodo asentamiento.

En la capital, liberales comprometidos y simpatizantes tuvieron que adaptarse al ambiente amenazador de la reacción.Aún así, muchos jóvenes ex-milicianos no tropezaron con obstáculos insalvables porque la represión fue, al fin y al cabo, discriminada. La actividad política que no había sobrepasado los límites de la fogosidad juvenil no estorbaba tanto y el castigo se dirigió prioritariamente contra líderes significativos -como Riego o, poco después, el Empecinado- lo que aumentaba sin duda la ejemplaridad de las represalias. Así, buena parte de los jóvenes proliberales logró desenvolverse en medio de aquel clima de rigurosa vigilancia manteniendo su inquietud política contenida.

A pesar del celo de las comisiones de purificación literaria, Bretón de los Herreros logró estrenar su primera obra de teatro en 1824, aunque, como indicaba el marqués de Molins, «lo consiguió [...] ocultando el nombre del liberal que le había dado el ser $\rangle^{31}$. Aquel primer éxito compartió cartel con otro drama de Ventura de la Vega, desde entonces gran amigo de Bretón, y ambos fueron presentados en público en el Teatro del Príncipe el día 14 de octubre, no por casualidad la fecha del cumpleaños de Fernando VII. Es a partir de estos momentos cuando la posición política del escritor se vuelve ambigua e intenta adaptarse a los nuevos tiempos. Bretón empezó a cultivar en los círculos literario-políticos de la época las amistades de algunos de los hombres más significativos del romanticismo. A través de su relación con Ventura de la Vega, entró en contacto con Larra, Patricio de la Escosura o Mesonero Romanos, todos ellos de intachable carácter liberal y alumnos del Colegio de San Mateo regido por Alberto Lista. Pero no hay que olvidar que este último, aunque partidario de las ideas liberales, había defendido durante el Trienio la teoría de la monarquía templada que perseguía la implantación de un sistema constitucional prudente capaz de ganarse apoyos desde arriba, incluido el del propio Fernando VII. La propuesta de Alberto Lista se oponía al modelo de revolución exaltada y trató de hacer converger las distintas opiniones constitucionales en torno a la búsqueda del justo medio como única solución posible para resolver los conflictos que axfisiaban al Trienio ${ }^{32}$. La academia de Lista impartía una enseñanza de alta calidad para lo más granado del cuerpo social. En su estudio sobre Espronceda, Robert Marrast señaló el acusado elitismo del Colegio de San Mateo donde «por anticipado y por trimestre» los alumnos internos pagaban « 4.400 reales en la enseñanza primaria y 6.000 en la secundaria; [...] los medio pensionistas $2.200 \mathrm{o}$ $3.000 ; y[\ldots]$ los externos, 1.000 o $1.500 \aleph^{33}$. Entre los discípulos de Lista figuraron, además de los citados, Juan de la Pezuela, conde de Cheste; Mariano Roca de Togores, marqués de Molins; Manuel Mazarredo, Luis María Pastor, Espronceda o Ventura de la Vega; y a partir de 1825 el mismo Bretón de los Herreros ${ }^{34}$.Todos los alumnos de Lista, incluidos algunos exaltados, guardaron un buen recuerdo del maestro y ello a pesar de su tendencia política, siempre templada e incluso oportunista.

31. ROCA DE TOGORES, M., MARQUÉS DE MOLINS, 1892: 10.

32. Sobre el pensamiento de Lista y su significado político en elTrienio, véase ELORZA, A., 1990: 146-153.

33. MARRAST, R., 1989: 31-32.

34. MARRAST, R., 1989: 43 
Integrado en el grupo de alumnos de Lista y aprendiendo de aquellas lecciones políticas, Bretón decidió adaptarse a la situación. Poco a poco se fue apagando su antiguo fervor liberal al compás de la influencia que ejercían algunos de sus nuevos amigos, entre los que se encontraba Juan María Grimaldi, ahora principal empresario de los teatros de Madrid y poco antes comisario de guerra a las órdenes del duque de Angulema $^{35}$.A Bretón, los efectos beneficiosos derivados de cultivar estas amistades y el éxito de su primera representación dramática, debieron darle la pista sobre el camino a seguir. Es patente que en aquellos tiempos de férreo control y rigurosa observación, la supervivencia no pasaba justamente por la exhibición de ideas liberales, sino que dependía, muy al contrario, del mayor disimulo político posible. Teniendo en cuenta esta prioridad, Bretón fue suavizando sus inclinaciones proliberales y retrayendo el sentimiento político, que había calado hondo en toda su generación, hasta poder ser identificado esencialmente como un hombre de teatro. Al igual que Grimaldi, de parecido jaez eran otros conocidos de Bretón que se caracterizaron siempre por un interesado vaivén político y un eclecticismo ideológico oportunamente practicado. A algunos de ellos, Bretón los conoció en casa del hijo del marqués de Cortina y hermano del marqués de Morante, tertulias de contenido político y literario que Mesonero Romanos describió así en sus memorias:

«Por los años 1827 al 28 [...] nos reuníamos en grata compañía los domingos por la mañana en casa de don José Gómez de la Cortina [...] todos o casi todos (que no llegaríamos seguramente a una docena) los jóvenes dados por irresistible vocación a conferir con las musas [...]. Entre estos varios jóvenes, cuyos nombres fueron enaltecidos más adelante por sus trabajos literarios, recuerdo, además del amo de la casa, al distinguido diplomático don Nicolás Ugalde y Mollinedo [...]; al sabio y modesto humanista don José Mussó y Valiente, encargado con Cortina, por el rey Fernando de cuidar y dirigir la magnífica edición de las obras completas de Moratín, costeada por el mismo Monarca y estropeada por la censura; a Bretón de los Herreros y Gil y Zárate, que con sus primeras producciones dramáticas habían conseguido galvanizar un tanto el cadáver del teatro español; a don Rafael Húmara y Salamanca [...]; a don José del Castillo y Ayensa [...]; a don Patricio de la Escosura [...]; y más adelante a don Mariano José de Larra, alumno de medicina, a quien yo mismo presenté a Cortina a fin de que le recomendase al rey para que fuese nombrado individuo de una Comisión facultativa que había de ir a Viena a estudiar el cólera [...]; a Serafín Calderón [...]; al ingenioso Segovia [...]; al correcto y joven poeta Ventura de la Vega, en fin, que con sus magníficas octavas dirigidas al Rey, a su vuelta de Cataluña, acababa de recoger el cetro de nuestra lírica poesía ${ }^{36}$.

Mesonero añadía después que también en aquella tertulia había penetrado «a despecho de los gobernantes, el ambiente liberal que se respiraba en la atmósfera» y destacaba que incluso Fermín Caballero llegó a unirse poco más tarde al grupo de contertulios $^{37}$. Sin embargo es manifiesto el espíritu general que presidía aquellas reuniones, pobladas de individuos que con mayor o menor disimulo mantenían un coqueteo permanente con la autoridad absolutista. Quizá sea necesario recordar que mientras Bretón de los Herreros animaba las sesiones con graciosos chascarrillos y

35. Algunas noticias sobre el pasado de Grimaldi en MARRAST, R., 1989: 109 y 226-227.

36. MESONERO ROMANOS, R., 1975: 268-270.

37. MESONERO ROMANOS, R., 1975: 270 y 272 respectivamente. 
Ventura de la Vega dedicaba poéticas composiciones al rey, los Numantinos de Espronceda habían sido detenidos, disueltos y recluidos y multitud de liberales esperaban procesos sumarísimos en la cárcel de la villa.

Además de la tertulia de Cortina, el dramaturgo frecuentó otros salones donde tuvo oportunidad de ampliar su círculo de compañías. Según Marrast, Ventura de la Vega, el conde de Cheste, Gil de Zárate, Carlos O'Donnell, Larra y Bretón eran habituales en casa de Aristizábal, mayordomo de Palacio; de Mariátegui, arquitecto municipal; de Rives, famoso cirujano; o del jurista Manuel María Cambronero ${ }^{38}$. No sería de extrañar que en casa de este último, Bretón y Olózaga hubieran tenido sus primeros contactos. Salustiano de Olózaga conoció bien a Cambronero y aunque no hay noticias ciertas, son altamente fiables los indicios de que Salustiano pudo ser por estas fechas pasante en su bufete ${ }^{39}$. En cualquier caso, para Bretón tenía más importancia, por el momento, la presencia en aquellas tertulias de Juan María Grimaldi y de otro personaje, José María Carnerero, jerifalte del periodismo madrileño. Los hermanos Carnerero se iniciaron en la carrera periodística dirigiendo el Memorial Literario o Biblioteca periódica de Ciencias y Artes en los primeros años del siglo y José María Carnerero colaboró además con la prensa afrancesada publicando algunos artículos en la Gaceta y en el Diario de Madrid. Con José Bonaparte redactó la Gaceta de Madrid y durante el Trienio dirigió el periódico oficial de la Sociedad Landaburiana, llamado primero Indicador de las Artes y los Espectáculos y después El Patriota Español.Más tarde, con la restauración del absolutismo, reapareció en el mundo de los noticieros, parece que publicando junto con Agustín Durán el Diario Literario $y$ Mercantil, modesto intento de introducir cierto debate literario. El Diario tuvo una existencia efímera, pero tres años después, el Correo Literario y Mercantil recuperó aquella misma línea periodística, esta vez con más acierto y con la tendencia política adecuada. Más tarde publicó, con el amparo de María Cristina, Cartas Españolas y, después de la muerte de Fernando VII, La Revista Española ${ }^{40}$.

El Correo empezó a publicarse bajo la dirección de Carnerero en julio de 1828. Para entonces el editor ya se había ganado una merecida fama de oportunista y habilidoso tránsfuga. Según $\mathrm{M}^{\mathrm{a}}$ Cruz Seoane, su vida fue «pródiga» en sorprendentes giros políticos y Carnerero resultó ser «una especie de camaleón político, un caso pasmoso de adaptación al medio ${ }^{41}$. Aunque extensa, merece ser apuntada aquí la descripción que hizo Mesonero Romanos del periodista, testimonio de gran interés para observar el comportamiento político de Carnerero:

«Bajo el aspecto político, este biforme personaje era un tipo especial de volubilidad y travesura. Protegido en sus primeros años por el poderoso valido Príncipe de la Paz [...] ensayó ante sus aras el humeante incensario, que luego habŕa de manejar en la corte de José Napoleón, como uno de sus áulicos, y redactor literario de la Gaceta de Madrid [...]; a su vuelta de la emigración, consagrando su lisonjera pluma a los corifeos de las diversas opiniones liberales, desde Matínez de la Rosa y Conde de Toreno hasta el bando comunero y la sociedad demagógica titulada La

38. MARRAST, R., 1989: 112-113.

39. Véase PASTOR DÍAZ, N., 1842:4. También da cuenta de la misma noticia PÉREZ GALDÓs, B., 1976: 90.

40. Los principales apuntes sobre la actividad de Carnerero, en SEOANE, $M^{a} C$., 1989: 134-135.

41. SEOANE, $M^{2}$ C., 1989: 134 
Landaburiana. Concluido aquel sistema [...] hizo un cuarto de conversión y halló modo de sentarse a la mesa del Duque de Angulema, declarándose furibundo realista, y tanto que al regreso del Monarca escribió e hizo representar una comedia titulada La noticia feliz, que por lo ultraexagerada podía arder en un candil. Desdeñado, empero, por aquel Gobierno durante largo tiempo, tardó mucho en rehabilitarse y penetrar en las antecámaras del Palacio, pero al fin penetró por la mediación del ministro Ballesteros y el comisario de Cruzada Varela, y pudo obtener de Fernando VII el privilegio exclusivo de publicar un periódico o revista literaria que tituló Cartas Españolas, y que, como buen cortesano, puso bajo el amparo y protección de la reina María Cristina, y cuando esta augusta señora se encargó de la gobernación del reino, a consecuencia de la muerte de Fernando VII, Carnerero, obediente como un girasol, fundó el periódico La Revista Española, hallando en ella el medio de prodigar el humo de su incienso a los diversos matices políticos que se sucedieron, hasta que en $1838,[\ldots]$ arrojó su incensario a las plantas (que no a las narices) del altísimo Mendizábal $»^{42}$.

Desde abril de 1831 Bretón de los Herreros fue redactor del Correo Literario y Mercantil a las órdenes de Carnerero. Por su filiación absolutista, el periódico nunca tuvo buena acogida entre los liberales, pero todavía despertó más recelos cuando se vinculó la desaparición de $E l$ Duende Satírico de Larra con las malas artes de Carnerero. Larra había criticado en $E l$ Duende el carácter insustancial y ramplón del Correo dirigiendo contra su propio inspirador algunas de sus acostumbradas mofas.A partir de diciembre de 1828 , El Duende dejó de publicarse y parece que aquella requisa pudo deberse a una oportuna intervención de Carnerero ante las autoridades absolutistas ${ }^{43}$. Con la retirada de la única revista crítica, el Correo no tuvo ya rival alguno y se mantuvo activo hasta 1833, cuando un mes después de la muerte del rey, concluía también, y no por casualidad, su trayectoria periodística.

Desde que su primera obra de teatro se estrenara en el día del cumpleaños del rey, la vida de Bretón estuvo salpicada durante la década ominosa de constantes flirteos con el poder absolutista. En 1828 una representación teatral preparada para jalear a Fernando VII que volvía a Madrid después de sofocar en Cataluña una insurrección ultrarreaccionaria, incluyó en su cartel otra obra de Bretón y, al año siguiente, el escritor publicó una pieza para celebrar las bodas reales de Fernando y María Cristina de Nápoles ${ }^{44}$. En el Correo Bretón también derrochó alabanzas para el poder y dedicó abundantes felicitaciones al monarca absoluto. Así tenía que ser, porque el periódico de Carnerero era considerado sin dudas un órgano de expresión reaccionario. El propio Bretón atestiguó esta cualidad cuando, ya en 1836 y para agradar a otras téndencias políticas de signo bien distinto, recordaba refiriéndose al Correo:

«no hay cosa como escribir bajo la sombra de un solio, y ejercer el monopolio de desbarrar y mentir ${ }^{45}$. 
Mientras iban llegando las colaboraciones en el Correo Literario, Bretón siguió frecuentando tertulias y reuniones. Integrado plenamente en el pequeño círculo de próceres, sus encuentros tenían lugar en el que fue el más famoso corrillo político y literario de la época: el Parnasillo. Parece que su fundación se produjo a finales del año 30 y además de los antiguos alumnos de Lista -conocidos también como el grupo de la Academia del Mirto- fueron asiduos hombres políticos y futuros parlamentarios como Fermín Caballero, González Bravo, Joaquín María López, Bravo Murillo o el mismo Olózaga. Pero también destacaban en aquel vivero intelectual los habituales Grimaldi y Carnerero. Cuenta Mesonero Romanos que inaugurado el Parnasillo

«dividiéronse luego los asociados en las correspondientes secciones (o pandillas, si place al lector) de los líricos, de los dramáticos, de los bucólicos, de los críticos, de los prosistas, de los satíricos, de los afines, de los discordes, de los entusiastas (todavía no se habían inventado los románticos), de los innumerables matices, bandas y comuniones [...]. Alli, al frente de la mesa que pudiéramos llamar presidencial, el dictador teatral, Grimaldi, tendía el paño y disertaba con gran inteligencia sobre el arte dramático y la poesía; alli Carnerero, con su amena y sabrosa conversación, sus animados cuentos, chistes y chascarrillos $[. .$.$] formaba las delicias de los jóvenes$ poetas $\aleph^{46}$.

También Bretón de los Herreros empezó a ser bien conocido en aquella reunión, donde supo desplegar «su alegre y franca espontaneidad característica $[y]$ su prodigiosa facultad para versificar ${ }^{47}$. Aquellas virtudes, además de su adecuada actitud en lo político, debieron cautivar a Carnerero que, poco despues, en abril de 1831, nombró a Bretón redactor de la sección literaria de su periódico; justamente el año en el que la represión volvió a recrudecerse. 1831 fue, en efecto, una etapa clave para el liberalismo español. El triunfo de las revoluciones del 30 en el contexto europeo, había infundido nuevos ánimos. Además, el gobierno de Fernando VII arrastraba una profunda crisis y la tensión en el bando absolutista había crecido desde que en marzo de 1830 el rey reinstauró la pragmática sanción, asegurando así la posibilidad de una sucesión femenina en el trono de España. La escisión de los ultras terminó por consumarse cuando Fernando VII se vio obligado a reconocer en julio de 1830 , el éxito de los revolucionarios franceses y la monarquía de Luis Felipe de Orleans. Aprovechando la situación interna y coincidiendo con el avance revolucionario en Europa, el liberalismo español intensificó su guerra de desgaste. Mina y Torrijos dirigieron todos los movimientos desde el exilio, y en el interior se aceleraron los planes subversivos para hacer triunfar la insurrección de 1831. Pero al régimen fernandino todavía le quedaban arrestos. Una vez más, la tentativa fracasó y el liberalismo siguió acumulando gloriosas víctimas. Mariana Pineda, Torrijos o el librero Miyar fueron las más célebres del último episodio de impiedad absolutista.

Durante la década ominosa, ni Bretón ni la mayoría de sus amoldados compañeros literarios, se complicaron en ninguna de las batallas clandestinas del liberalismo. Salvo excepciones como el apasionado Espronceda o el mordaz Larra, buena parte de aquel distinguido grupo del Parnasillo declinó adoptar un compromiso político abier-

46. MESONERO ROMANOS, R., 1975: 296.

47. MESONERO ROMANOS, R., 1975: 296. 
tamente favorable a las ideas liberales. Más bien se mantuvo a la sombra del mejor árbol y optó por divulgar una identidad exclusivamente literaria; hábil mecanis mo de protección que ya venía demostrando su buen funcionamiento. Así pués, Bretón, Mesonero, Gil de Zárate, Escosura o Ventura de la Vega, pasaron los años de absolutismo haciendo literatura que Marrast calificaba de "mediano talento" y salieron indemnes de la represión política a base de no desairar las voces de mando ${ }^{48}$.

Después del duro varapalo del año 31, a punto estuvieron de cumplirse las expectativas del liberalismo cuando a mediados de 1832, la salud de Fernando VII se agravó de forma inesperada. Una sorprendente recuperación volvió a frustrar el proyecto revolucionario que tendría que esperar hasta la muerte del rey en 1833 . No obstante, la situación dio un giro espectacular en el último año del reinado absolutista. Valiéndose de la enfermedad de Fernando VII, los partidarios de la sucesión del infante don Carlos habían obligado al monarca a derogar la ley reimplantada que garantizaba el reinado de su hija Isabel. Pero su reanimación truncó la conjura de los ultrarrealistas. El rey anuló el decreto de derogación que él mismo había firmado y, convencido por sus consejeros -más conscientes que nunca del peligro carlista-, puso en marcha una nueva estrategia para asegurar el trono de Isabel. Nombró regente a su esposa María Cristina y se encargó a Cea Bermúdez la formación de un nuevo gobierno. En octubre de 1832, la primera medida de la regente fue decretar la amnistía política que autorizaba el regreso de los refugiados liberales. El objetivo no era otro que agrupar fuerzas para defender la futura monarquía de Isabel II. A finales de septiembre de 1833 moría Fernando VII dejando como herencia una guerra civil, el último obstáculo y no el menos difícil, que separaba a la burguesía revolucionaria del triunfo definitivo de sus ambiciones políticas.

La CONSTRUCCIÓN DEL Estado bURGués. PARLAMENTARISMO Y MONARQUÚA CONSTITUCIONAL (1834-1840).

La muerte de Fernando VII precipitó la anunciada guerra civil y dio paso a una dificil situación política. El gabinete Cea y la reina regente buscaban, con la tímida apertura del régimen, hacer frente a una sucesión monárquica percibida como ilegítima, pero en ningún momento habían previsto un cambio político irreversible. Ambos empezaron a ser criticados duramente por amplios sectores liberales que no podían admitir que, mientras se solicitaba su ayuda para luchar contra el carlismo, tratara de contenerse su proyecto político mediante posturas, más que tibias, sencillamente ambiguas. El nuevo gobierno no estaba dispuesto a tolerar que la participación del liberalismo en los destinos políticos del país reprodujera los efectos de pasadas experiencias constitucionales. Sin embargo, la causa de la futura reina necesitaba un apoyo firme y sólido. Así pues, la regente no tuvo más remedio que correr el riesgo y hacer concesiones a los sectores liberales que, dentro de un moderantismo invocado por la gran mayoría, se inclinaban por un sistema constitucional sobre el que construir el futuro político. Su primera condición exigía prescindir de Cea, acusado de promover un inmovilismo nefasto para sus intereses. Y la segunda, proporcionar a la nación un marco legal donde quedaran normalizadas las libertades burguesas. Martínez de la

48. MARRAST, R., 1989: 252. 


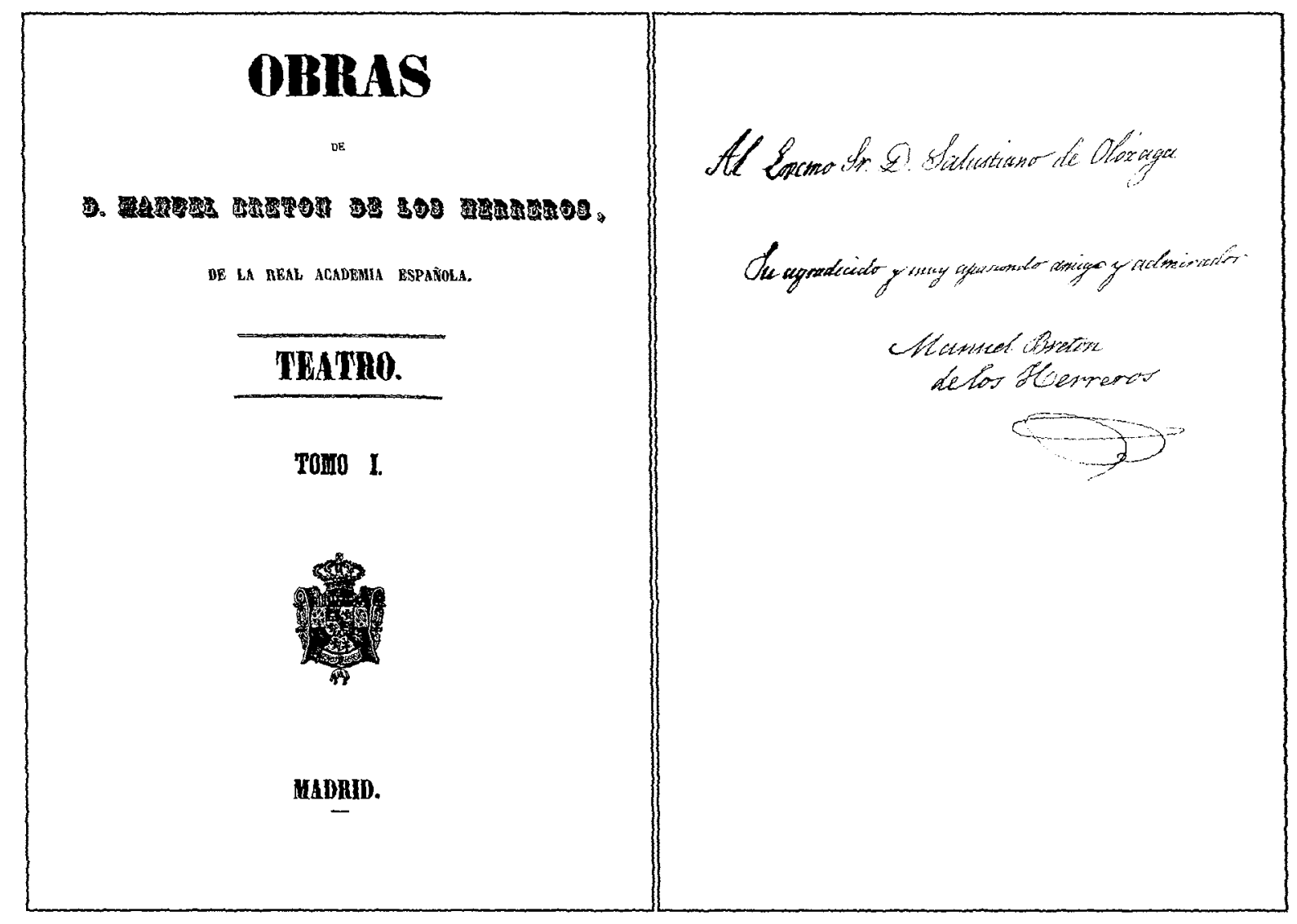

Dedicatoria de Bretón de los Herreros a Olózaga en un ejemplar de la edición de sus Obras de 1850.

Fuente: Biblioteca particular de D. Ramón Querol Muller (Madrid). 
Rosa, recién llegado del exilio, sustituyó a Cea Bermúdez y su pasado político, moderado pero vinculado a la representación constitucional durante el Trienio, ofreció garantías a todas las tendencias liberales. A los pocos meses de su entrada en el Ministerio de Estado, en abril de 1834 se promulgaba el Estatuto Real, obra política con la que se convocaba la apertura de Cortes y daba comienzo el sistema representativo.

En este nuevo contexto político también la literatura y el periodismo volvieron a florecer. Con la llegada de los emigrados y la libertad de los recluidos, la prensa se revitalizó y las letras enseguida pudieron beneficiarse de la apertura del Ateneo y de la introducción de debates teóricos acerca de asuntos tan principales como, por ejemplo, el romanticismo.Además del Correo Literario y Mercantil, desaparecido días después de la muerte de Fernando VII, Bretón colaboró en algunos periódicos más, aunque todavía moderados como aconsejaban los tiempos. La ley de censura no fue modificada hasta 1836 y la normativa que regulaba la prensa era realmente estrecha a pesar de la apertura política. Bretón escribió en La Aurora de España, refundado en 1833, o El Universal, suprimido en mayo de 1834 y reaparecido un mes después con el nombre de $L a$ Abeja, periódico que volvería a cambiar su título por el de La Ley en 1836. Pero en este mismo año participó, incluso, en uno de los más arriesgados, el Boletín de Comercio, fundado por Fermín Caballero y convertido poco después en el Eco del Comercio, la voz oficial del progresismo ${ }^{49}$. Según el marqués de Molins, era un comportamiento lógico en un Bretón que empezaba a significarse políticamente en favor de la futura Isabel II:

"Ni hay para qué sorprenderse de que Bretón, buscado antaño para redactar la crítica dramática, sin olor siquiera de política, fuese subvencionado ahora para escribir letrillas archi-políticas, militantes, satíricas, agresivas si se quiere; y la elección era acertada, porque el benévolo autor de Los dos sobrinos y A Madrid me vuelvo era el isabelino autor de El triunfo de la inocencia, el liberal improvisador de Los car istas en Portugal, que ponía al servicio de la causa parlamentaria las eminentes dotes poéticas del autor de Marcela" $"$.

Bretón no se transformó en un furibundo liberal como podría deducirse del testimonio del marqués de Molins, pero sí en un isabelino más. El pulso político del momento estaba cerrando filas en torno a la causa de Isabel II y no pocos amigos del dramaturgo tomaban posiciones, unas más y otras menos radicales, alrededor del nuevo régimen y en defensa de la monarquía constitucional. Pronto Bretón empezó a cosechar los frutos de aquel conveniente giro político. Isabelino, pero bien moderado, en 1834 obtuvo su primer puesto en la nueva administración gracias a Javier de

49. La Abeja fue uno de los periódicos más importantes durante esta etapa de transición. Desde sus páginas apoyó la solución moderada del Estatuto Real y mostró lealtad a Martínez de la Rosa. Su postura fue criticada por la prensa de oposición que, a la menor oportunidad, descalificaba al periódico por ministerial. El Boletín de Comercio, que precedió al Eco del Comercio, apareció en 1832 y desde el principio fue el más agresivo. Primero con Cea Bermúdez y después con todos los gabinetes ministeriales que defendían reformas tímidas y cambios moderados. En la dirección del Eco participaron, además de Fermín Caballero, progresistas destacados como Ángel Iznardi o Joaquín María López. Véase SEOANE, Ma C., 1989: 149-152. Para el Boletín y el Eco resulta particularmente interesante un artículo de Juan Sisinio Pérez Garzón, donde se explica cómo Javier de Burgos nombró a Bretón de los Herreros en 1834 redactor-inspector del Boletín de Comercio con la intención de "embridar [la] impaciencia revolucionaria» de este periódico. Véase PÉREZ GARZÓN, J. S., 1983: 512-513.

50. MARQUÉS DE MOLINS, 1883: 166. 
Burgos, Ministro de Fomento, que le colocó en la Subdelegación de su Ministerio en Madrid. Después, debido a sus buenas relaciones, Bretón pudo mantener su cargo cuando los progresistas llegaron al poder y, de la mano de Mendizábal, Olózaga fue nombrado Gobernador Civil de Madrid. Según el marqués de Molins, Salustiano de Olózaga fue siempre uno de sus más seguros valedores; pero hubo otros, como el duque de Rivas que, en 1836 y siendo Ministro de la Gobernación en el gabinete Istúriz, le nombró bibliotecario segundo de la Biblioteca Nacional, institución que más tarde le acogería como director ${ }^{51}$.

Pero en esta etapa crítica para la consolidación del liberalismo, tuvo lugar un acontecimiento clave que junto con el desarrollo de la prensa vino a dinamizar la actividad política y literaria: la fundación del Ateneo. En 1835 la agrupación de notables que componian la Sociedad Matritense de Amigos del País propuso la creación de un Ateneo como el que existiera en la anterior etapa constitucional de 1820. Entre los miembros de la selecta asociación ya figuraban escritores como Mesonero y Ventura de la Vega o destacados políticos como Salustiano de Olózaga; y su proyecto concentró a otros muchos personajes ilustres de aquellos mismos círculos como el duque de Rivas, el marqués de Molins, Argüelles, Alcalá Galiano, Martínez de la Rosa, Espronceda, Gil de Zárate, el omnipresente Grimaldi y el afamado Bretón de los Herreros. En su primera reunión se eligieron los siete miembros que tendrian que componer la Junta Provisional del Ateneo, organismo que se encargaría después de convocar las elecciones para adjudicar la presidencia y distribuir los demás cargos. Bretón obtuvo 14 votos, pero no fueron suficientes para formar parte de la Junta. Entre aquellos siete interinos resultaron los más votados Olózaga y el duque de Rivas, siendo finalmente este último el primer presidente del nuevo Ateneo ${ }^{52}$.

Lógicamente, el funcionamiento del Ateneo estaba ligado de manera inevitable al discurrir político.Y la situación del régimen parlamentario en España, pasado el principio de una acogida comúnmente celebrada, empezaba a enturbiarse. Los que pronto serán conocidos como progresistas habían comenzado a criticar el Estatuto de Martínez de la Rosa poco después de ser promulgado. La sensación de que el Estatuto era una concesión monárquica se extendió entre el sector liberal más proclive al pro gresismo, dentro de la indefinición que caracterizaba a las distintas posturas políticas en estos primeros momentos. Su argumento, parecido al de los exaltados del Trienio, ponía el acento en que soluciones moderadas como el Estatuto favorecían al enemigo carlista en la medida en que no permitían la unión de todas las fuerzas antirreaccionarias. La amenaza del carlismo y por consiguiente el peligro que corría el proyecto político de la burguesía, preocupaban por igual a todas las tendencias liberales, pero

51. Véase una exposición más amplia de todos estos datos en GIL DE ZÁRATE,A., 1842: 49-50; o también en MOLINS, 1883: 206-207. La amistad que unió a Olózaga y Bretón se mantuvo a lo largo de sus vidas. Como se aprecia en el documento 4 del apéndice, Olózaga dejó incluso constancia pública de aquella relación, promoviendo en 1870 un homenaje al dramaturgo en su pueblo natal.

52. Sobre la fundación del Ateneo de Madrid, pueden verse los testimonios -con categoria de fuente histórica - de MESONERO ROMANOS, R., 1975:362-367; o de LABRA, R. M. DE, 1878: 64-86. Entre los estudios actuales que se han ocupado de analizar el papel desempeñado por el Ateneo, véanse por ejemplo, GARRORENA MORALES, A., 1974; o también las numerosas referencias de Marrast en su trabajo sobre Espronceda. 
como ya ocurriera en el Trienio, una vez más las diferencias se iban a establecer en torno a los métodos para alcanzar los objetivos.

Ante las presiones, Martínez de la Rosa tuvo que dimitir sumido en un profundo descrédito. En junio del año 35, Toreno se hizo cargo del gobierno, también templado y conciliador, pero con intención de colmar las inquietudes de los más avanzados, colocó a Mendizábal al frente del Ministerio de Hacienda. Ni así logró satisfacer aquellas expectativas y después de las algaradas ciudadanas del verano, tuvo que dejar el poder en manos de Mendizábal, figura señaladamente progresista. La brecha abierta en la familia liberal se manifestó en todos los frentes políticos y también en el Ateneo. La orientación moderada de la gran academia intentó ser modificada durante el gobierno de Mendizábal. Entre los progresistas que tenían algún peso dentro de la institución, Olózaga sobresalía de manera especial y además su capacidad de influencia se había visto reforzada por su puesto de Gobernador Civil. Desde aquel cargo intentó promover el acceso de los progresistas a las cátedras del Ateneo, ocupadas hasta el momento por moderados recalcitrantes; circunstancia que contribuye a demostrar que antes que foro de discusión científica y literaria, el Ateneo fue, en aquella etapa histórica, un avispero político, que discurría paralelo al desarrollo del propio régimen parlamentario y a la formación lenta y ambigua de las posiciones moderada y progresista $^{53}$. Desde su relación con el Ateneo y la integración entre sus miembros más destacados, Bretón empezó a participar en el Semanario Pintoresco, periódico fundado por Mesonero en 1836 y alentado por el espíritu ateneísta de la moderación. El Semanario quiso ser una revista de contenido amplio, pero alejado lo más posible del acalorado debate político; característica perpetua en la personalidad de su propio fundador y compartida, claro está, por sus colaboradores ${ }^{54}$.

Pero muy pronto, el ritmo acelerado de los acontecimientos iba a exigir de todos los sectores liberales una definición comprometida con el proyecto político de la burguesía. La fuerza que estaba alcanzando el bando carlista empezaba a llenar de dudas a los defensores de Isabel II. El desenlace de la guerra civil, dada su creciente intensidad, hacía temer seriamente un nuevo fracaso del sistema constitucional. Durante su gobierno y a pesar de que fue su primera preocupación, Mendizábal no pudo contener el furor carlista. Tampoco Istúriz, su sustituto al frente de un nuevo gabinete, encontró la fórmula para debilitar al carlismo y, acusado de interrumpir las reformas mendizabalistas y frenar la solución radical del conflicto, tuvo que enfrentarse a la sonada contestación progresista que tuvo su punto culminante en la rebelión de los sargentos de la Granja. La reina regente fue obligada a jurar la constitución de 1812, Calatrava -otra figura visible del progresismo - se hizo cargo de un nuevo gobierno y terminó así el limitado margen político del Estatuto Real. Bajo la cobertura legal de la reinstaurada Constitución del 12, se celebraron las elecciones de octubre del 36 y dio comienzo una nueva legislatura en la que la trascendencia de los asuntos a debatir, iba a marcar el futuro del sistema constitucional.

53. Las intenciones de Olózaga las contó Mesonero Romanos, a la sazón secretario del Ateneo. Mesonero reproduce en sus Memorias parte de una conversación que mantuvo con el Gobernador Civil. Olózaga le manifestó su desacuerdo con la lista de candidatos a las cátedras del Ateneo por ser todos ellos de una misma tendencia política y propuso al secretario, encontrar «algunos de otro color». Ver MESONERO ROMANOS, R., 1975: 365-366.

54. Sobre la fundación y la evolución histórica del Semanario Pintoresco, SEOANE, Mª C., 1989: 167-170. 
Desde la apertura de las Cortes en octubre de 1836, la acción política concentró sus esfuerzos en dos objetivos principales: elaborar un texto constitucional acorde con las necesidades del recién inaugurado Estado liberal y procurar el fin definitivo de la guerra civil. Ambos cometidos eran de vital importancia para la consolidación del sistema y urgía la implicación de toda la ciudadanía en aquella tarea común. Con una intención conciliadora, capaz de reagrupar el mayor número posible de sensibilidades políticas, fue aprobada la Constitución de 1837; texto legal redactado por una comisión parlamentaria en la que Olózaga, actuando como secretario, desempeñó un papel fundamental. En junio de 1837 la reina sancionó la nueva Constitución y aquel modelo político, cuyos postulados básicos estaban destinados a perdurar en la historia del parlamentarismo español, iba además acompañado de un nuevo sistema electoral. Esta fue, sin duda, la pieza clave: de una buena ley electoral dependía el reclutamiento de las fuerzas necesarias para sostener el sistema y acabar con el enemigo carlista ${ }^{55}$.

A la altura de 1837 Bretón de los Herreros, que había estado al servicio de una política moderada y con un talante en apariencia indiferente, seguía colaborando en la prensa, componiendo pequeños poemas para el Museo Artístico $y$ Literario y era miembro de la Academia Española ${ }^{56}$. Pero a raíz de la convulsión provocada por los últimos acontecimientos y ante el vigor que demostraba el carlismo, dio un nuevo virage político y se prestó, incluso, a participar en las elecciones generales de octubre sumándose a la candidatura progresista. La maquinaria electoral desplegada por la Constitución del 37 había conseguido diseñar un censo que, dentro de la restricción consustancial al sufragio selectivo, ampliaba notoriamente la participación. Bretón fue incluido en las listas de la provincia de Logroño, pero como vamos a comprobar, nada tenía que ver aquella resolución con un capricho político.

A diferencia de la legislación del 12 y del Estatuto Real, la Constitución del 37 concibió un mecanismo electoral para incluir en el cuerpo de votantes el mayor número posible de propietarios. Con la amenaza de la guerra carlista, cuyo desenlace era imprevisible, el compromiso político se había inhibido y la ley electoral del 37 se encaminó claramente a desenmascarar la propiedad y obligarla a tomar partido. La defensa del trono isabelino era la garantía del sistema constitucional y el liberalismo necesitaba aumentar la implicación en contra del carlismo para salvar su proyecto político. Con la intención de ampliar los apoyos, el sistema electoral extendió cuanto pudo el derecho al voto tratando de involucrar en la lucha por la construcción del Estado, a todos los representantes de la propiedad. Pero no era suficiente para su identificación recurrir a la contribución porque, entre otras cosas, el sistema hacendístico heredado del Antiguo Régimen favorecía en multitud de casos la ocultación de la riqueza. Así pues, la ley estableció las condiciones para ser elector y elegible atendiendo a otros muchos criterios económicos. El primero comprendía a todos los ciudadanos que pagaran como mínimo 200 reales anuales de contribución directa. El segundo afectaba a quienes tuvieran una renta líquida anual «que no baje de 1.500 rea-

55. Para comprender la importancia de la Constitución del 37 en la evolución del constitucionalismo español, son referencia básica los distintos artículos del número monográfico de la REVISTA DE DERECHO POLÍTICO, $\mathrm{n}^{\circ}$ 20, 1983-84; y el trabajo de TOMÁS VILLARROYA, J., 1981: 5-67.

56. Según Gil de Zárate, el primero de sus biógrafos, su ingreso en la Academia tuvo lugar en mayo de 1837. Véase GIL DE ZÁRATE,A., 1842:51. En cuanto a la participación de Bretón en el Museo Artístico, ver SEOANE, $M^{a}$ C., 1989: 170. 
les, procedente de predios propios rústicos o urbanos, o de ganados de cualquiera especie o de establecimientos de caza o pesca, o de cualquiera profesión para cuyo ejercicio exijan las leyes estudios y exámenes preliminares». Este segundo punto incluía además a los labradores con una yunta destinada al cultivo de tierra propia, razón suficiente para tener derecho a voto sin necesidad de justificar su renta. El tercero abarcaba a los que, en calidad de arrendatarios o aparceros, pagaran al menos 3.000 reales de renta anual; y también los labradores con dos yuntas, utilizadas para trabajar su propia tierra o la que llevaran en arrendamiento. Por si no fuera suficiente, la cuarta condición buscaba a los que habitaran una casa o cuarto pagando de alquiler al menos 2.500 reales anuales en Madrid, 1.500 en ciudades de más de 50.000 habitantes, 1.000 en pueblos con más de 20.000 vecinos y 400 reales en el resto ${ }^{57}$. Desde luego la propiedad iba a ser encontrada por leve que fuera su rastro.

Estos eran los requisitos que marcaba la ley tanto para ser elector como para resultar elegido.Alguno de ellos cumplía Bretón de los Herreros, aunque no podemos averiguar cuál. En el censo debía figurar junto al nombre del elector el criterio por el que quedaba incluido, pero debido a los problemas que hubo en la provincia de Logroño para publicar las listas en el Boletín Oficial, no sabemos qué condición fue aplicada en el caso de Bretón ${ }^{58}$. De cualquier manera, su decisión de participar en la lucha electoral respondía no tanto a su, cada vez más fuerte, vinculación con Olózaga -apuntada en ocasiones como causa forzada de aquella "aventura" política- sino a una convicción, muy extendida entre los defensores isabelinos, de apoyar la legitimidad constitucional frente al avance reaccionario de las fuerzas carlistas ${ }^{59}$. Pero además, parece que a esta inclinación general, Bretón sumaba la simpatía con tendencias progresistas, no muy bien definidas todavía, pero partidarias de las soluciones más contundentes para lograr la erradicación del carlismo. Así mismo se desprende de una carta que Bretón dirigió al marqués de Molins en vísperas de la convocatoria electoral. En ella, animaba a su colega a «trabajar» en favor del triunfo electoral que «la gente honrada desea» y después justificaba sus propias razones:

\begin{abstract}
«Algunos parientes y amigos de mi tierra, se proponen favorecerme con sus votos, y valga lo que valiere, yo no rehuso la candidatura, porque creo deber hacer este sacrificio más por la buena causa. [...] Los partidos bullen y se agitan para triunfar en las elecciones. Parece que el de la legitimidad no se descuida, $y$ hay esperanzas de que salgan buenas ${ }^{60}$
\end{abstract}

57. Todos los datos mencionados proceden del Real Decreto de Ley electoral publicado en el Boletín Oficial de la Provincia de Logroño (en adelante B.O.P.Lo.) el 18 de julio de 1837. Un estudio pormenorizado sobre esta ley electoral y sus efectos, en TOMÁS VILLARROYA, J., 1965; y también CASES MÉNDEZ, J. I., 1977.

58. En una circular, el Jefe Político de la Provincia, Ángel Iznardi, mostraba su «extrañeza» ante la falta de celo de los Ayuntamientos en la elaboración de las listas electorales. Advertía del «perjuicio» que esto causaba a los vecinos con derecho a voto e instaba a los Ayuntamientos a exponer las listas «inmediatamente». Véase B.O.P.Lo., 31 de agosto de 1837.

59. La relación entre Olózaga y Bretón de los Herreros ha sido subrayada en numerosas ocasiones, pero quien más claramente lo señaló fue el MARQUÉS DE MOLINS, 1883: 207, 221, y sobre todo 365. Llevado por la interpretación de Molins, Bernardo Sánchez Salas resaltaba la «evidencia» de que la candidatura de Bretón «fue una operación política no tanto del propio dramaturgo como orquestada por Olózaga» y después calificaba de «aventura»su participación en las elecciones. Ver SÁNCHEZ SALAS, B., 1990: 22 y 23 respectivamente.

60. MARQUÉS DE MOLINS, 1883: 221. 
Así las cosas, Bretón fue candidato a diputado por la provincia de Logroño, aunque la ley del 37 ya no exigía que el elegido tuviera en la provincia por la que salía diputado, su residencia, propiedad o nacimiento. La opción de presentarse por Logroño respondía, por lo tanto, a una estrategia bien sencilla: calcular dónde era más fácil obtener buenos resultados. En Logroño, los progresistas creyeron tener bajo control la canalización de los votos que arrastraría Salustiano de Olózaga, convertido ya para el año 37 en una figura política muy influyente en el panorama nacional. Pero además, como se verá más adelante, contaban con un apoyo decisivo en el vértice mismo del sistema electoral. Las elecciones empezaban a funcionar en los distritos, divisiones territoriales dentro de la provincia que la legislación autorizaba a organizar en función de la comodidad electoral. Logroño fue dividida en doce ${ }^{61}$. Los electores de cada uno de ellos tenían que emitir su voto en la población designada cabecera de distrito. Una vez celebrada la elección, que ahora duraba cinco días, se procedía al recuento de los votos y a la redacción del acta, documento que posteriormente, un comisionado nombrado por la mesa del distrito se encargaría de presentar ante la Junta Electoral en la capital de la provincia para el escrutinio general de los votos. A la provincia de Logroño le correspondían tres diputados y un suplente, nombramiento que en virtud de la ley había de producirse por mayoría absoluta en primera vuelta o relativa en segunda. Después del escrutinio general, la Junta de Logroño declaró elegidos diputados a Andrés Almarza con 1.012 votos y al Marqués de Someruelos con 864, ambos de tendencia moderada. Para designar al tercer diputado titular y al suplente hubo que realizar una segunda votación entre los candidatos que, sin obtener la mayoría absoluta, habían sido los siguientes más votados en la primera ronda. Nueve individuos componían aquella lista, progresista casi en su totalidad, de los cuales Olózaga figuraba en cuarto lugar con 628 sufragios y Bretón de los Herreros ocupaba el último puesto, el noveno, con 250 votos $^{62}$. El proceso se inició otra vez en los distritos y el 19 de octubre la Junta de la capital procedió al recuento de la segunda vuelta. Con 676 votos, Olózaga volvió a ser elegido diputado por la provincia de Logroño, aunque a la vista de los resultados los progresistas debieron tener que emplearse a fondo ${ }^{63}$. Aquellas elecciones, celebradas en un clima de tensión agudizado por la dimisión de Calatrava y las sucesivas renuncias de Espartero y Bardají a ocuparse del gobierno, acabaron favoreciendo a los moderados; probablemente mucho más diestros en los manejos electorales que serán, incluso en esta etapa tan temprana, moneda corriente en todas las convocatorias. Los cargos municipales, la composición de las mesas y sobre todo, las funciones de Gobernador Civil o Jefe Político de la provincia, tenían en la inmensa mayoría de los casos la llave para alterar, antes o después, los resultados electorales ${ }^{64}$. Pero en esta ocasión y a pesar de que los progresistas controlaban los puestos de responsabilidad en numerosas provincias, los moderados se habían organizado

61. B.O.P.Lo., 31 de agosto de 1837.

62. Como ya recogió SÁNCHEZ SALAS, B., 1990:23, los resultados aparecen en el Acta del escrutinio general de votos de la provincia de Logroño en las presentes elecciones a Diputados a Cortes y Senadores. B.O.P.Lo., 8 de octubre de 1837 .

63. Acta del escrutinio general de votos de la provincia de Logroño en la $2^{\text {a }}$ elección de Diputados a Cortes y Senadores. B.O.P.Lo., 5 de noviembre de 1837. También en SÁNCHEZ SALAS, B., 1990: 24.

64. Sobre las muchas y diversas artimañas electorales durante todo el reinado isabelino, véase el trabajo de CABALLERO, M., 1994, en el que la autora demuestra para la provincia de Soria la existencia temprana de todo tipo de trampas, más sofisticadas conforme se iba adquiriendo más experiencia. 
mejor. No se lo pusieron fácil en Logroño a los candidatos progresistas, a pesar de tener como Jefe Político de la provincia al mejor de los aliados, Ángel Iznardi, un progresista radical y buen amigo personal de Olózaga y Bretón que, desde la época de las tertulias hasta su paso por el Eco del Comercio, venía recorriendo junto a los riojanos una misma trayectoria.

Victoriosa en las elecciones de octubre, la mayoría moderada dominó la nueva legislatura y Ofalia, ministro durante el reinado de Fernando VII, fue el encargado de dirigir el gobierno. El nombramiento de un antiguo colaborador del absolutismo como jefe de gabinete hirió profundamente a los progresistas y la oposición parlamentaria, encabezada por Olózaga, retomó el tono furioso de sus ataques políticos. En este contexto, tuvo lugar en Logroño la elección parcial de febrero de 1838, en la que Bretón volvió a estar presente. Al ser nombrado el marqués de Someruelos Ministro de la Gobernación, hubo que celebrar nuevas elecciones para cubrir una vacante de diputado $^{65}$. Sujeto a reelección, volvió a salir Someruelos, pero el siguiente candidato más votado, dada la no concurrencia de Olózaga y otros progresistas significados, fue Bretón de los Herreros. No obstante, en aquel momento de dominio político moderado, sus votos fueron escasos. De los 1.074 emitidos, Someruelos obtuvo 928 y Bretón tan sólo $85^{66}$. Es evidente que el control electoral de los moderados volvió a actuar, pero además Bretón no respondía exactamente a la figura de diputado que las oligarquías locales necesitaban en Madrid. Se bușcaba, ante todo, un buen mediador, cuya influencia en el centro de la actividad política pudiera repercutir eficazmente en los intereses particulares de los poderes provinciales. Esta fue la razón principal por la que Bretón de los Herreros, pese a la participación electoral que mantuvo todavía en una ocasión más, nunca pudo obtener el acta de diputado; algo sabido de antemano y que tampoco le había obsesionado en absoluto, como demuestra su propia confesión política en aquella carta que dirigiera al marqués de Molins. Así, a partir de la votación parcial, su techo electoral se fue reduciendo hasta apagarse definitivamente. En julio de 1839 tuvo lugar una nueva consulta electoral. Esta vez, la convocatoria general favoreció a los progresistas que, habiendo tomado buena nota de su fracaso anterior, prepararon mejor la táctica propagandística y planificaron más ordenadamente la intervención en el proceso. En Logroño se denunciaron por primera vez irregularidades en la votación y especialmente en el distrito de Arnedo, feudo del progresista Salustiano de Olózaga ${ }^{67}$. Con fraudes, cacicadas y manipulaciones, cada vez más y mejor preparadas, el recuento definitivo de los votos proclamó diputados a Olózaga y

65. La convocatoria fue anunciada por el Gobierno Político de la Provincia en el Boletín Oficial del 4 de febrero de 1838.

66. Acta del escrutinio general de votos de la provincia de Logroño. B.O.P.Lo., 8 de marzo de 1838

67. En la Junta Electoral de la Provincia se hicieron constar distintas quejas, que en el caso de Arnedo denunciaban graves infracciones en la constitución de la mesa del distrito. Acta del escrutinio general de votos de la Provincia de Logroño en las actuales elecciones. B.O.P.Lo., 11 de agosto de 1839. Salustiano de Olózaga tuvo estrechos vínculos con Arnedo y especialmente con Vico. Había nacido en Oyón en 1805, pero su padre obtuvo una plaza de médico titular en Arnedo; localidad riojana en la que permaneció la familia hasta 1819. Sin perder nunca los lazos con Arnedo, de cuya base oligárquica dependió siempre su triunfo electoral en la provincia, en 1843 y en el contexto de la desamortización impulsada bajo la regencia de Espartero, Olózaga compró el monasterio franciscano de Vico. Con sus tierras, y otras fincas rústicas que adquirió en Arnedo, formó una explotación agraria familiar que estuvo siempre al cuidado de su hijo Salustiano Félix de Olózaga y Camarasa. Pero además el encumbrado político hizo de Vico una villa de recreo al estilo burgués donde pasó, a lo largo de su vida, todos los periodos de descanso y retiro. 
Cenón María Adana. Para designar el tercer diputado que correspondía a la provincia hubo que elegir en segunda vuelta a uno de los candidatos que sin alcanzar mayoría absoluta hubieran resultado ser los más votados. También en esta lista, de la que salió elegido finalmente Ramón Alesón, volvía a figurar Bretón de los Herreros, que ocupó con 692 votos el quinto puesto ${ }^{68}$. Aún así, a la hora de la verdad, Bretón fue relegado, porque los poderes locales no lo consideraron un hombre con suficiente influencia política. En la segunda vuelta, sus 692 votos se convirtieron en 13 y es muy significativo comprobar cómo candidatos, incluso situados por detrás en el primer escrutinio, fueron en la segunda ronda más votados que Bretón. Este fue el caso de José de Olózaga, hermano del prestigioso Salustiano, convertido ya a estas alturas en un famoso orador parlamentario, principal dirigente del progresismo y hombre perfectamente ubicado en la telaraña del poder político. Por esta razón, José de Olózaga, que había obtenido 290 votos frente a los 692 de Bretón, era mucho más adecuado y así, en la segunda vuelta, fue respaldado por 216 sufragios frente a los 13 de Bretón ${ }^{69}$.

Aquí acabó aquel «sacrificio» al que se refirió el dramaturgo en su correspondencia con Molins. Bretón no volvió a presentar su candidatura en más elecciones. En algunos de sus biógrafos parecen asomar tentaciones de atribuir su retirada a una frustración personal o a un final lógico de lo que según su percepción no puede considerarse más que una fantasía política o incluso una extravagancia del literato ${ }^{70}$. Sin embargo, y una vez más, hay una explicación histórica capaz de dar sentido tanto a su participación electoral como a su distanciamiento después de la última convocatoria. Tras las elecciones de julio de 1839 , se inició el nuevo curso político con los mejores augurios para el proyecto revolucionario de la burguesía. Espartero y Maroto firmaron el conocido Convenio de Vergara el 31 de agosto y, aunque Cabrera siguió actuando en el Maestrazgo hasta el verano de 1840 , la guerra civil se podía dar por terminada. En esta situación nueva, que aseguraba ya el futuro de la monarquía isabelina y el desarrollo del régimen parlamentario, Bretón podía reducir su nivel de implicación. Aún vendrían más sobresaltos políticos, nunca apaciguados hasta la Restauración, pero el obstáculo más peligroso para el anclaje definitivo del trono constitucional de Isabel II había sido vencido. Ahora la construcción del Estado burgués avanzaba sólidamente y con paso firme hacia su consolidación.

68. Los resultados en ibid.

69. En la segunda vuelta volvió a haber problemas en Arnedo y la elección fue anulada por las Cortes. La votación tuvo que repetirse y los resultados indicados arriba, proceden del Acta del escrutinio general de votos de la provincia de Logroño en la repetición de las segundas elecciones. B.O.P.Lo., 7 de noviembre de 1839.

70. Así parece considerarlo Molins que insiste en el carácter casi anecdótico que tuvo aquella aproximación de Bretón a la política activa. Su amigo y biógrafo minimiza esta «tentación» y le interesa acentuar por encima de todo que la «vida entera» del poeta estuvo consagrada al «cultivo de las musas». Véase MARQUÉS DE MOLINS, 1883: 221 y 305 respectivamente. 


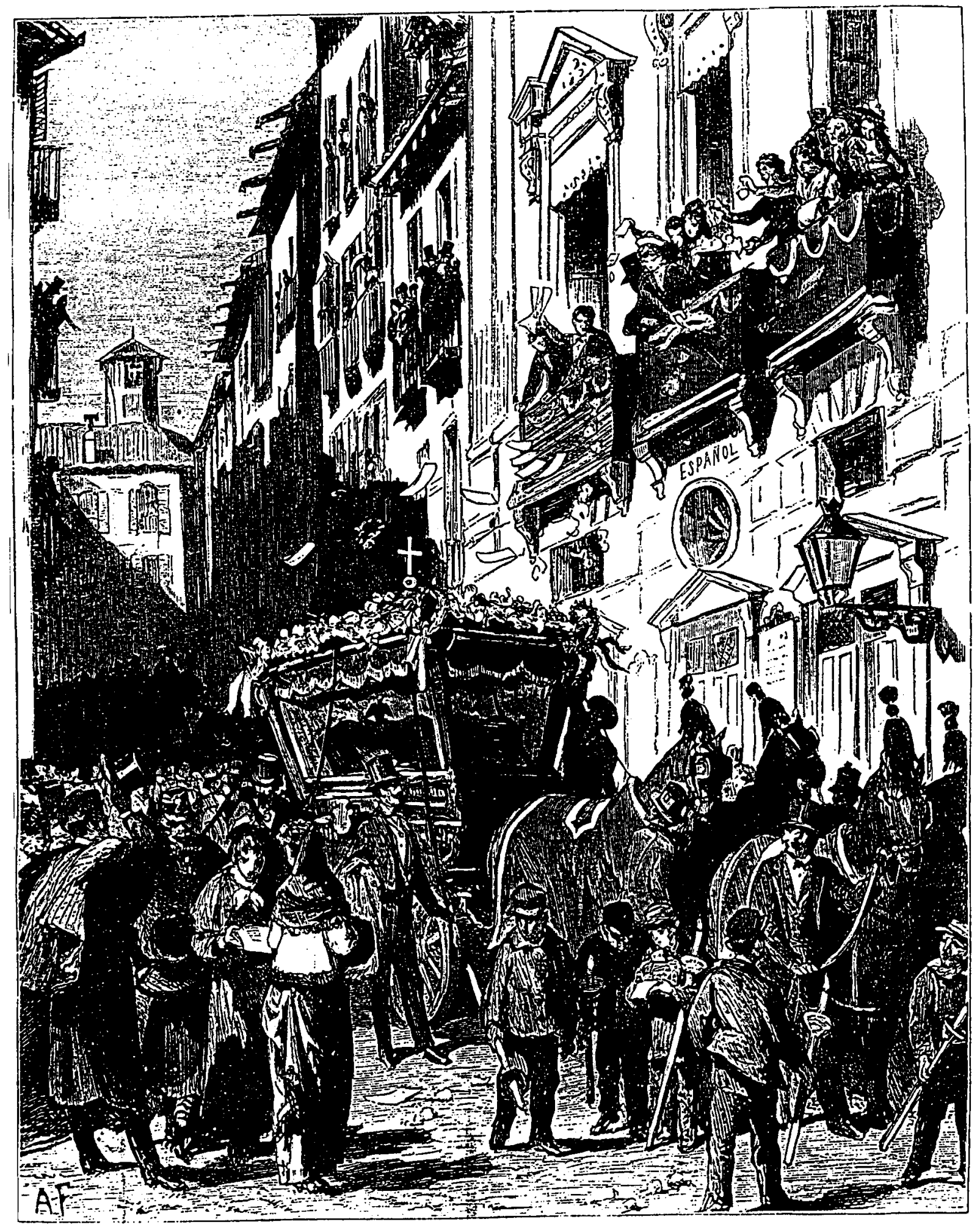

Entierro de Bretón de los Herreros en Madrid

Fuente: La Ilustración Española y Americana, 24-XI-1873, p. 708. 


\section{APÉNDICE DOCUMENTAL}

\section{DOCUMENTO 1}

Expediente militar de Manuel Bretón de los Herreros

Corregimiento de Caballerla Costa de Granada. $2^{a}$ Compañta

\section{Soldado}

Manuel Bretón hijo de Antonio y de Petra Herreros natural de Quel dependiente al Corregimiento de Calaborra y avecindado en su pueblo su oficio Estudiante su estatura: 5 pies 3 pulgadas = líneas, su edad 17 años, S.R.C.A.R. sus señales estas: pelo castaño claro ojos pardos color moreno cejas como el pelo nariz regular barbilampiño.

Fue destinado al Batallón de Voluntarios de Aragón por [ilegible] años en Alicante a cinco de septiembre de mil ochocientos doce y se le leyeron las penas que previene la Ordenanza, y lo firmó quedando advertido, de que es la justificación, y no le servirá disculpa alguna, siendo testigos los sargentos $1^{\circ}$ y $2^{\circ}$ Tomás Bollant y Esteban Márquez $=$ Manuel Bretón=

\section{Nota:}

Prestó el juramento de fidelidad a los Estandartes. Otra: sentó plaza voluntariamente en el Batallón de A caballo de Ávila en 24 de mayo de 1812 en el que ha servido hasta el cinco de septiembre del presente año, en que fue destinado a este Cuerpo según queda manifestado. Otra: la nota que antecede está formada según la exposición del filiado =Espadas=. Otra: pasó a esta compañía en $1^{\circ}$ de octubre de 1812. Rubricada. Se le depuso de la Escuadra por haberse separado en la marcha de Alicante a Tobarra y haber enajenado sus cartuchos. Tobarra, 18 de abril de 1812. Espada=. Otra: pasó con ascenso a cabo segundo a la $6^{\mathrm{a}}$ Compañía en 28 de julio del presente año de 1813 . Como encargado del detall $=$ Bunio $=$. Otra: ascendió a cabo $1^{\circ}$ en $1^{\circ}$ de enero de $1815=$ Enriquez=. Otra: se le consideran dos años y un mes por el tiempo pasivo de campaña con arreglo a Reales ordenes. Otra: pasó a este de Cazadores de Madrid en virtud de Real orden de 15 de agosto de 1817. Otra: tuvo entrada en este regimiento procedente del extinguido Cazadores de Madrid en $1^{\circ}$ de julio de $1818=$ Aranda.

Es copia a la letra de la original que existe en esta oficina de mi cargo y el individuo comprendido en ella, pasa al depósito de ultramar a continuar sus servicios ajustado y satisfecho de todos sus haberes y raciones por fin del mes de octubre venidero, lo que certifico como coronel de los Reales Ejércitos y teniente coronel del expresado cuerpo. Murcia, veinte y dos de septiembre de mil ochocientos diez y ocho.

$$
\mathrm{V}^{\circ} \mathrm{B}^{\circ}
$$

Tuvo entrada en este del Rey $1^{\circ}$ de Ligera en $1^{\circ}$ de noviembre de 1818 siendo procedente del contingente de la Costa de Granada.

Este individuo siendo procedente del contingente de la costa de Granada, no se ha incorporado; quedó con licencia temporal en Aguilar y como no justifica se le da de baja en 28 de mayo de 1819.

Huerta

Se presentó en el Regimiento el đía $1^{\circ}$ de agosto de 1819 , acreditando suficientemente haber estado enfermo todo el tiempo que ha faltado desde que fue a disfrutar la licencia temporal, por cuya causa no deberá servirle de ningún obstáculo la nota anterior.

\section{Huerta}

Salió con licecia absoluta el día 8 de marzo de 1822, cuyo documento le fue expedido en mayo de 1820 y no lo ha disfrutado hasta el día de hoy.

Fuente:Archivo General Militar. Segovia, Leg. B-3.740 


\section{DOCUMENTO 2}

Solicitud de Petra Herreros

Señor

$D^{a}$ María Petra de los Herreros, viuda de Don Antonio Bretón, y vecina de esta Corte, puesta a los Reales Pies de V.M. con la mayor veneración, expone: que habiendo fallecido su esposo en la pasada guerra quedó en el más deplorable estado y sin otros bienes que seis hijos, todos de menor edad. Manuel, uno de ellos, de edad de quince años, tomó las armas en defensa de vuestra causa y a la sazón se halla sirviendo a V. M. en clase de cabo primero en el Batallón Infantería ligera de Volutarios de Aragón, y a pesar de ser el mencionado Manuel el único que pudiera aliviarla en su indigencia por tener dos de sus hijos casados, y ser el mayor de los restantes de edad de catorce años, no duda sacrificar su propio interés a la complacencia de considerarle útil en el Real servicio, pero teniendo la suplicante un hermano capitán en el Regimiento de Caballería de Madrid, $4^{\circ}$ de Cazadores, que es Don Florentino de los Herreros desea que al menos sirva en su Compañía donde su constitución será correspondiente a su nacimiento; por tanto, a V. M. rendidamente suplica se digne conceder al expresado Manuel Bretón el pase de soldado al dicho Regimiento de Caballería, gracia que espera conseguir de la innata piedad de V. M. en unos días tan plausibles a toda la Nación y queda rogando a Dios por su importante vida. Madrid, 18 de febrero de 1816. Señor: A los R. P. de V. M. Petra Herreros.

Fuente:Archivo General Militar. Segovia, Leg. B-3.740

\section{DOCUMENTO 3}

CONCESIÓN DE LA SOLICITUD

Ministerio de Guerra. Exmo. Señor:

Al Inspector General de Infantería digo con esta fecha lo siguiente: Enterado el Rey de la instancia de $\mathrm{D}^{\mathrm{a}}$ María Petra de los Herreros, que solicita que a su hijo Manuel Bretón, cabo $1^{\circ}$ del Batallón de Infantería Ligera $1^{\circ}$ de Voluntarios de Aragón, se le conceda pasar a continuar sus servicios en clase de soldado al regimiento de Caballería Cazadores de Madrid, ha tenido a bien S. M. condescender con su solicitud.

De Real orden lo traslado a V. E. para su instancia y efectos convenientes, en contestación a su oficio de 25 de Junio anterior. Dios guarde a V. E. muchos años. Palacio, 7 de agosto de 1817. Firma.

Fuente:Archivo General Militar. Segovia, Leg. B-3.740

\section{DOCUMENTO 4}

ACTA NOTARLAL DEL HOMENAJE A BRETón

«En la villa de Quel, distrito notarial de Arnedo, provincia de Logroño, a veinte y cuatro de Octubre de mil ochocientos setenta, yo el infrascripto, Notario del Colegio de Abogados, D. Toribio José de Irizar, vecino de la ciudad de Arnedo, previo el oportuno requerimiento, me constituí en las salas consistoriales de esta referida villa, y por el Sr. Alcalde popular de la misma, asistido de todos los individuos que componen la municipalidad y demás personas que abajo se mencionan, se dijo: Que por el Exmo. Sr. D. Salustiano de Olózaga, Diputado a Cortes por esta provincia, se había hecho 
saber a la corporación que presidía, el deseo que hace tiempo abrigaba de que se colocase una lápida en la casa sita en esta villa, donde nació el eminente, fecundo y popular poeta Exmo. Sr. D. Manuel Bretón de los Herreros, a fin de que se perpetuara su memoria para emulación de todo el país riojano, y especialmente de esta referida villa de Quel, que tiene la satisfacción de haber sido su cuna; y que habiendo llevado a efecto tan laudable propósito y deseo, había regalado al Muy Ilustre Ayuntamiento la lápida que se hallaba de manifiesto, que contiene la inscripción siguiente "El diez y nueve de Diciembre de mil setecientos noventa y seis nació en esta casa el fecundo y popular poeta D. Manuel Bretón de los Herreros"; que agradeciendo y admitiendo la municipalidad con la mayor complacencia y emoción, tan generosa y patriótica demostración, había acordado la colocación de dicha lápida, señalada para tan solemne acto, este día y hora de las diez de su mañana ${ }^{71}$. En su consecuencia el mencionado Sr. Alcalde; D. Miguel Bacigalupe, D. Manuel Oñate, D. Isidoro Aldama, D. Matías Martínez, D. José Manuel Marzo, D.Antonio Marzo y D. Ecequiel Marzo, Regidores;

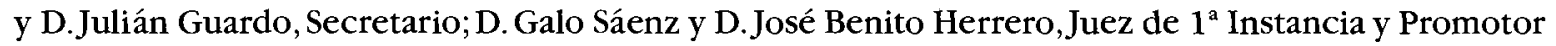
Fiscal, respectivamente, de este partido; D. Manuel Martínez Nieva, Juez municipal de esta villa; el Exmo. Sr. D. Salustiano de Olózaga; D. Antonio San Martín; D. Pedro Agustín Herrero, Diputado provincial; D. Salustiano Ruiz, Magistrado de la Audiencia de Barcelona; D. Severo Martínez,Alcalde de la ciudad de Calahorra; D. Salustiano Vega, Director del Colegio de sordo-mudos y ciegos de Burgos; D. Salustiano Solís y Muro, Profesor de instrucción primaria de esta villa; D. Salustiano de Olózaga y Camarasa; Da Dolores Herreros y Bretón, Da Agustina Bretón y Sáenz, Da Inés de los Herreros, D. Sotero Sánchez Malo de los Herreros, D. Lázaro Sánchez Malo de los Herreros, D. Tomás Sánchez Malo de los Herreros, D. José Alonso y Garcés, D. Nicolás Bretón y Sáenz, D. Francisco Javier Malo, D. Marcelino Herrero, D. Luis de la Mata, D. Cayetano Sánchez Malo, D. Francisco Oñate, D. Elías Sánchez, D. Gonzalo Martínez, D. José Eguizábal y D. Juan Francisco Solana, sobrestante de obras públicas, y D. Valentín del Cerro, Profesor de $1^{\text {a }}$ enseñanza en Villanueva de Cameros ${ }^{72}$, se trasladaron siendo la hora señalada a la casa $n^{\circ} 1^{\circ}$ sita en la calle del Medio de esta villa, en la que nació el Ilustre y eminente poeta Exmo. Sr. Don Manuel Bretón de los Herreros, y se procedió a la colocación de dicha lápida que es de bronce oxidado, teniendo efecto encima de la puerta principal de dicha casa, habiendo antes incrustado en un hueco preparado de antemano, detrás de dicha lápida, una caja de cinc, en la que se contenían dos tomos de las obras del mencionado literato y poeta, edición de París, y las composiciones que alusivas al acto le han dedicado los SS. D. A. M. Segovia, Cándido Bretón y Orozco, D. Gonzalo Martínez, D. Jerónimo Borao, D. Juan Eugenio Hartzenbusch y D. Francisco Oñate, las cuales fueron leídas antes en presencia de todos los concurrentes; con esta

71. Quizá este es uno de los pasajes de la vida de Bretón que más se ha repetido en todos sus retratos y semblanzas. El homenaje, que alentado por Olózaga se le tributó en su pueblo natal en 1870 , es muy conocido y ha sido descrito una y otra vez por sus biógrafos, principalmente por su sobrino Cándido. Pero además el documento original incluido aquí, se conserva en el Archivo Histórico Provincial de Logroño y aprovecho la ocasión para manifestar mi reconocimiento más sincero a Micaela; técnico del archivo que con su gratificante interés y habitual generosidad se encargó personalmente de hacerme llegar el documento.

72. La presencia en el acto de profesores y maestros responde a que Olózaga organizó previamente un certamen literario cuya clausura quiso hacer coincidir con el homenaje a Bretón de los Herreros. Véase SÁNCHEZ SALAS, B., 1990: 24-26. Aquella idea de Olózaga para premiar el talento en los discípulos aventajados surgió de un recuerdo muy antiguo. En su adolescencia, y gracias a su cualificada formación, el politico había ganado el premio que otorgaban cada año los franciscanos de Vico después de convocar a los mejores estudiantes del entorno. Según Fernández de los Ríos -biógrafo oficial de Salustiano de Olózagalos alumnos de los alrededores acudían al pórtico del monasterio el día de la Porciúncula para ser examinados por los frailes. La primera vez que asistió Olózaga, «al grito de ;Viva Arnedo! obtuvo [...] su primer triunfo». Véase FERNÁNDEZ DE LOS RÍOS,A., 1863: 96. La Porciúncula, término que procede del nombre del primer convento de la Orden de San Francisco, tenía especial significado para los franciscanos puesto que conmemoraba, cada 2 de agosto, la renovación de la indulgencia plenaria para los miembros de la orden. El relato no pasaría de mera anécdota si no fuera por la impresión que causó en Olózaga aquella sencilla distinción. Dos meses antes de su muerte, ocurrida en 1873, escribió una carta desde Enghien (París) dirigida a su hijo, donde, por ser un 2 de agosto, recordaba asombrosamente que «hoy hace 58 años que recibí en Vico mi primer premio literario". Archivo Privado Fernández de Navarrete. Correspondencia de Olózaga, documentos sin clasificar. 
acta que se levantó al efecto por duplicado, con lo que se dio por terminada siendo la hora de las doce y la firmaron los concurrentes, de todo lo cual, yo, el Notario, doy fe. Firmas».

Fuente:Archivo Histótico Provincial. Logroño, Protocolos Notariales, Vol. 5.766, ff. 54-56.

\section{DOCUMENTO 5}

DeClaración TESTAMENTARIA DE POBREZA LEGAL OTORGADA POR JOSÉ BRETÓN DE los HeRREROS EN 1875.

«En Madrid a doce de julio de mil ochocientos setenta y cinco, yo, Don José Bretón de los Herreros, natural de esta capital, hijo de Don Antonio y Doña Petra, difuntos, de sesenta y cuatro años de edad ${ }^{73}$, de estado viudo, cesante ${ }^{74}$, vecino de esta capital, con habitación en la Calle del Fomento, número uno duplicado, cuarto entresuelo de la izquierda, sin exhibir cédula personal por no encontrarla en este momento, hallándome enfermo en cama de la que Dios nuestro Señor se ha servido darme; pero esto no obstante, en mi entero y cabal juicio, creyendo como firmemente creo en el único prensible misterio de la Santísima Trinidad, Padre, Hijo y Espíritu Santo, tres personas distintas y un solo Dios verdadero y en todos los demás misterios, dogmas, artículos y sacramentos que tiene, cree y confiesa nuestra Santa Madre la Iglesia Católica,Apostólica y Romana, bajo cuya fe y creencia he vivido y protesto vivir y morir como buen cristiano; en tal concepto, temeroso de la muerte, cosa natural a toda criatura, aunque incierta su hora, deseando estar prevenido de disposición testamentaria para cuando aquella llegue, tomando en tan duro trance por mi Intercesora y Abogada a la Reina de los Ángeles, María Santísima, Ángel de mi guarda y Santos de mi nombre y devoción; hago y ordeno esta mi declaración en la forma siguiente.

En primer lugar declaro ser pobre en sentido legal sin poseer bienes, ni rentas de que poder tes$\operatorname{tar}^{75}$, por lo que suplico al Señor Cura Párroco o su Teniente de la en que ocurra mi fallecimiento y autoridad civil que corresponda, se sirvan mandar se me dé sepultura eclesiástica y ordenar el primero se celebren por mi alma los sufragios que su caritativa piedad tenga dispuestos en casos análogos.

Declaro haber estado casado con Doña Josefa Orozco, de cuyo matrimonio me han quedado y viven en la actualidad dos hijos llamados Don Cándido y Doña Josefa, ambos mayores de edad, lo que advierto y para que conste.

73. Como se desprende de la certificación testamentaria, José Bretón nació en 1811, año en el que murió el cabeza de familia. El dato corrobora la deducción de Felipe Abad que habiendo localizado en el Archivo Parroquial de Quel a cuatro de los hermanos Bretón, advirtió lógicamente que los demás habrían nacido en Madrid después de que la familia se trasladara a la capital. Véase ABAD LEÓN, F, 1977: 79-80.

74. El testimonio de José Bretón aclara que debió desempeñar algún puesto dentro de la función pública en el cuerpo administrativo del Estado. Este extremo, que no era un objetivo propio de esta investigación, es, no obstante, fácil de comprobar, puesto que se conservan los expedientes de clases pasivas en distintos archivos de Madrid; es decir, la información básica de las personas cuyo trabajo se desarrolló en la administración. Hasta 1911, los expedientes de clases pasivas se encuentran distribuidos en el Archivo Histórico Nacional y en el Archivo General de la Administración de Alcalá de Henares. Además, los índices de Matilla Tascón y de Vicente Cadenas facilitan su búsqueda. Esta documentación puede llegar a ser muy valiosa porque, en muchos casos, constan, además de los datos principales de toda la carrera funcionarial, partidas de nacimiento, matrimonio, o solicitudes de pensión que presentan los familiares después del fallecimiento del empleado. Sobre esta y otras fuentes que permiten la investigación biográfica y prosopográfica, pueden verse más detalles en AGUIRREAZKUENAGA, J.; SERRANO, S.; URQUIJO, J. R. Y M. URQUIJO, 1993.

75. Tan sólo de una pensión o subsidio debía disponer José Bretón como así lo acredita su declaración de pobreza legal, fórmula protocolaria al uso para consignar la inexistencia de otros bienes patrimoniales, dinero o haberes. Como veremos después, esta debió ser la razón por la que Bretón intentó favorecer en sus disposiciones legatarias a su hermano José. 
Por si al presente o en lo sucesivo me correspondiesen algunos bienes, derechos, acciones, futuras o ignoradas sucesiones, instituyo y nombro por mis únicos y universales herederos a mis dos referidos hijos, Don Cándido y Doña Josefa Bretón y Orozco, a los dos por iguales partes o sea por mitad, para que los que sean pocos o muchos y de la clase y condición que quiera los dé, cumpla y ejecute en aquella vía y forma que más haya lugar en derecho.

En cuyo testimonio así lo digo, otorgo y no firmo por el estado de debilidad en que me encuentro, a su ruego, a la vez que por sí, lo harán los testigos instrumentales que lo fueron Don Pedro Zaldivar y Huertas, Don Rafael de la Guardia y Ortega y Don Francisco Miguel de la Guardia y Heros, vecinos de esta villa sin excepción legal para serlo; y yo el Notario del Colegio y domicilio de esta capital Don Luis Hernández que doy fe del conocimiento del otorgante y de hallarse en su entero y cabal juicio, presente fui con los testigos a este otorgamiento en un solo acto leyendo integramente este instrumento a sus otros por haber renunciado todos al derecho que les advertí tenían para leerle por sí, de todo lo que también doy fe. Firmas".

Fuente:Archivo Histórico de Protocolos. Madrid,Vol. 31.743, ff. 2.115-2.118.

\section{DOCUMENTO 6}

Testamento de Manuel Bretón de los Herreros otorgado en 1854.

«En el nombre de Dios Todo-Poderoso, mi Criador, Señor de cielos y tierra, de la Inmaculada Concepción de la Virgen Santísima, de los Santos Ángeles de mi guarda de mi nombre y devoción, y de la Santa Religión Católica,Apostólica, Romana que profeso y cuyos misterios, artículos y sacramentos, creo: Yo, Don Manuel Bretón de los Herreros, vecino de esta corte, actual director de la Biblioteca Nacional y Secretario perpetuo de la Real Academia Española, natural de la villa de Quel en la Provincia de Logroño, de edad de cincuenta y siete años, hijo legítimo de los Señores D.Antonio Bretón y $D^{a}$ María Petra Herreros, natural el primero de dicha villa de Quel y la segunda de la de Nalda en la misma Provincia de Logroño ${ }^{76}$, ya difuntos; hallándome en buena salud, cabal juicio, memoria y entendimiento natural, y deseando estar prevenido con disposición testamentaria para cuando llegue mi muerte, cosa indudable a toda criatura humana aunque incierta su hora, OTORGO: Que hago y ordeno mi testamento, última y final voluntad en la manera siguiente. Lo primero, encomiendo mi alma a Dios que la crió y redimió con su preciosa sangre, y el cuerpo mando a la tierra de que fue formado.

Declaro que ni mi carácter ni mi limitada fortuna consienten que se me hagan funerales ostentosos; no quiero, pues, en mi entierro otros gastos que los absolutamente indispensables para que se conduzcan a la última morada con modesto decoro mis restos mortales. En sufragios para mi alma que contrictamente vuelvo a recomendar a Dios, se invertirán mil reales, y otros dos mil para socorro de los niños expósitos de esta corte.

Declaro que mi muy amada consorte, la Señora $D^{a}$ Tomasa Andrés, y yo, otorgamos en veinte y nueve de Noviembre de mil ochocientos treinta y nueve, un poder mutuo para testar el uno por el otro, esto es, el sobreviviente por el que primero falleciere. Pero al presente, sin rebajar yo en lo más mínimo el tierno amor y la cumplida confianza que entonces justamente me inspiró mi cara esposa, pues, al contrario cada día he tenido y tengo nuevos motivos para bendecir a Dios por haberme dado tan envidiable compañera, considerando primero, que los términos en que aquel mutuo poder se halla redactado pudieran ocasionar a mi esposa (en el caso muy probable de sobrevivirme, como humilde y cristianamente se lo ruego al Altísimo) las molestias de inventarios, particiones y otras no menos sensibles y dolorosas; segundo, que no tengo ya como en aquella fecha herederos forzosos, pues falleció con posterioridad mi Señora Madre (Q.E.E.G.) y la divina Providencia no me ha dado

76. El testamento de Bretón confirma que su madre era natural de Nalda, aunque esta circunstancia debió ser casual, según apuntó ABAD LEÓN, F, 1977: 83. 
hijos, y a fin de simplificar en lo posible el cumplimiento de mi postrera voluntad, sin separarme del espíritu que dictó la mencionada disposición de veinte y nueve, quiero que mi referida cónyuge, sea la única y universal heredera de cuantos bienes de todo género poseo en el día o en adelante pudieren corresponderme, sin obligación de dar cuenta ni razón de ellos a persona alguna, y quedando obligada solamente a cumplir las mandas y cláusulas siguientes.

De la suma total a que asciendan los valores que yo a mi tránsito mortal poseyere y que consistan precisamente en metálico, en billetes del Banco de San Fernando, acciones del mismo, títulos al portador o inscripciones nominativas de las deudas públicas consolidada o diferida, y otros documentos análogos correspondientes a empresas del Gobierno o particulares, inclusas las cantidades que consten en recibos o apuntes que conserve en aquella hora y me sean en deber personas de mi familia, $o$ de la de mi mujer, y otras con quienes estoy relacionado ${ }^{77}$; de la suma total, repito, de estos designados valores, y no de otros, se sacará la cuarta parte, y esta se distribuirá por vía de manda o legado entre mis queridos hermanos y sobrinos cuyos nombres voy a expresar, y en los términos y proporciones siguientes. Dicha cuarta parte se dividirá en diez partes iguales y de ellas percibirá tres mi hermano D. José Bretón, dos mi hermana $D^{a}$ Petra Bretón; otras dos mi sobrina $D^{a}$ Luisa Figueroa y Bretón, una mi hermana $\mathrm{D}^{\mathrm{a}}$ Carlota Bretón, otra mi sobrina $\mathrm{D}^{\mathrm{a}}$ Agustina Bretón, y otra mi sobrino D. Félix Figueroa y Bretón, advirtiendo que las citadas diez mandas nominales se entiende que pasarán respectivamente a los hijos legítimos de los que fallecieren antes que yo, y respecto de mi hermana Doña Petra a su hijo adoptivo Don Antonio de las Peñas; y si ya no existieren tampoco dichos hijos, la manda correspondiente se distribuirá por partes iguales entre los demás legatarios nombrados. Amo a toda mi familia, pero al repartir entre ella una parte de mis escasos ahorros he debido consultar las mayores o menores necesidades de sus individuos y el grado en que cada uno ha grangeado mi afecto y empeñado mi gratitud $^{\text {s/ }}$.

Quiero y encargo muy especialmente que en la designación del metálico y demás valores especificados de que se ha de sacar la cuarta parte legada, todos han de estar y pasar por lo que declare y manifieste dicha mi consorte Doña Tomasa Andrés, de cuya recta conciencia estoy bien cierto y seguro como de la mía propia, y a quien me complazco en dar esta última prueba de mi entrañable cariño, por que con sus altas prendas y ejemplares virtudes ha labrado en vida mi felicidad y cuando yo deje de existir sabrá, no lo dudo, honrar mi memoria. Y además es mi voluntad que se la conceda por los legatarios un término prudente, que no bajará de dos meses, para vender con el menor quebranto posible, los créditos públicos al precio corriente en la plaza, y hacer pago de los legados en dinero.

Haría un agravio a los nobles y tiernos sentimientos de mi fiel consorte si le dirigiera recomendación alguna en favor de su familia, que me merece tanto cariño como la mía propia, y singularmente la angelical Teresita Andrés, mi sobrina política, que nacida casi en mis brazos, ha sido tantas veces con sus juegos y caricias infantiles, el bálsamo de mis dolencias y el consuelo de mis amarguras.

Cumplidos y pagados los legados que acabo de especificar, dejo por mi única y universal heredera del remanente de todos mis bienes, derechos y acciones presentes y futuros, a mi referida resposa, Doña Tomasa Andrés, a quien de consiguiente no se molestará en lo más minimo con operaciones de inventario $y$ partición que son de todo punto innecesarias, priesto que sacadas aquellas designadas

77. No conocemos en cirras el alcance de los ahorros ni de las distintas opciones inversoras que enumera Bretón. Es presumible que la suya no hera una fortuna ni siquiera notable. Pero la exposición testamentaria proporciona inaicios suficientes para pensar que Bteton. como miemioro de un grupo socia:

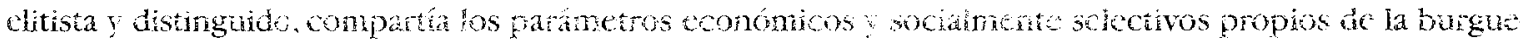
sia española del XIX.

76. Resulta interesante comprobar los distintos grados de afectivide cie Bretón profesa a sus herma

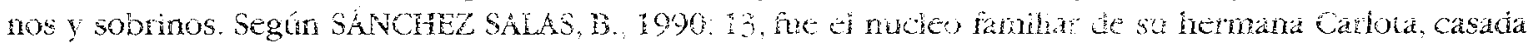

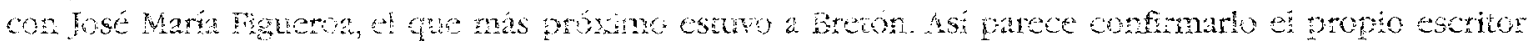

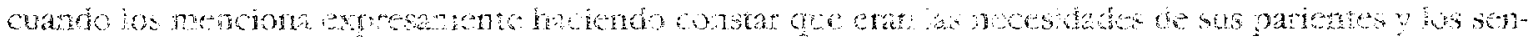

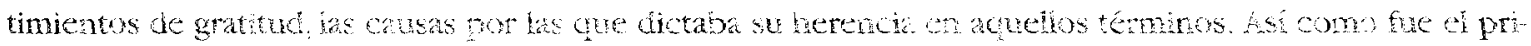

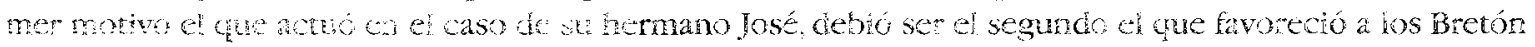

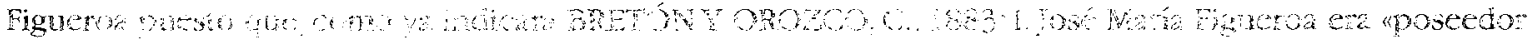

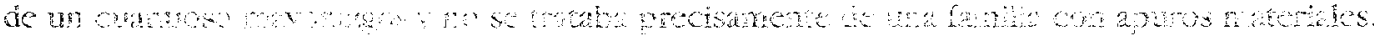


mandas, queda dueña y árbitra de cuanto yo posea, lo mismo dentro de mi casa que fuera de ella, sin excluir la propiedad de las obras de mi ingenio, tanto impresas como inéditas.

Nombro por mis albaceas testamentarios a los Señores D. Gregorio Cañete y Ponce, a Don Juan Eugenio Hartzenbusch y a Don Vicente Cuadrupani, a quienes ruego que como memoria de mi afecto y estimación, acepten cada uno tres obras de mi librería a su elección.

Y por el presete revoco y anulo en lo que a mi concierne el repetido poder para testar otorgado en veinte y nueve de Noviembre de mil ochocientos treinta y nueve, única disposición testamentaria que he formalizado durante mi vida, para que no valga ni haga fe, en juicio ni fuera de él, excepto este testamento que quiero y mando se tenga por mi última y deliberada voluntad, en la forma que más haya lugar en derecho. A cuyo fin, así lo otorgo y firmo, ante el presente Secretario honorario de S. M. Escribano Notario de Reyno y del Colegio de esta villa y corte de Madrid, en ella a veinte y ocho de septiembre de mil ochocientos cincuenta y cuatro, siendo testigos, D. José María Ayús, D. Benito Rozas, D. Pedro Padilla, D. Felipe de Landaburu y Rafael Borra, vecinos y residentes en esta corte. De todo lo cual, conocimiento del señor testador y de hallarse en su sano juicio, yo el Escribano, doy fe [...] Firmas».

Fuente: Archivo Histórico de Protocolos. Madrid,Vol. 25.932, ff. 1.411-1.415. 


\section{BIBLIOGRAFÍA CITADA}

ABAD, F, 1977

"Notas genealógicas y posición económica familiar de Bretón de los Herreros": Berceo, 92, pp. 73-95.

AGUIRREAZKUENAGA, J.; SERRANO, S; URQUIJO, J. R. y M. URQUIJO, 1993

Diccionario biográfico de los Parlamentarios de Vasconia (1808-1876), Vitoria.

ALCALÁ GALIANO,A., [1955]

Recuerdos de un anciano, Madrid.

ARTOLA, M., 1968

La España de Fernando VII:Tomo XXXII de Historia de España dirigida por Menéndez Pidal, Madrid.

ARTOLA, M., 1974

La burguesía revolucionaria (1808-1874), Madrid.

BALDÓ LACOMBA, M., 1988

"Fernando VII":A. Domínguez Ortíz, dir., Historia de España. 9. La transición del Antiguo al Nuevo régimen (1789-1874), Barcelona, pp. 179-305.

BRETÓNY OROZCO, C., 1883

"Introducción": Obras de Don Manuel Bretón de los Herreros, Tomo I, Madrid.

BURDIEL, I., 1987

La política de los notables (1834-1836), Valencia.

CABALLERO, M., 1994

El sufragio censitario. Elecciones Generales en Soria durante el reinado de Isabel II, Ávila.

CASTELLS, I., 1989

La utopía insurreccional del liberalismo, Barcelona.

DÍEZ TABOADA, J. M. y J. M. ROZAS, eds., 1965

Manuel Bretón de los Herreros. Obra dispersa. I. El "Correo Literario y Mercantil), Logroño.

ELORZA,A., 1990

"La ideología moderada en el trienio liberal": La modernización política en España, Madrid, pp. 141-236.

FERNÁNDEZ DE LOS RÍOS,A., 1863

Olózaga. Estudio político y biográfico, Madrid.

FONTANA, J., 1983 ( $5^{\text {a }}$ ed.)

Cambio económico y actitudes políticas en la España del siglo XIX, Barcelona.

FONTANA, J., 1987

"Per qué van envair Espanya els Cent Mil Fills de Sant Lluís?": Recerques, 19, pp. 17-33. 
FUENTES, J. F., 1989

"El Trienio Liberal en la correspondencia del Duque de Wellington": Boletín de la Real Academia de la Historia, Tomo CLXXXVI, Cuaderno III, pp. 407-442.

GARRORENA MORALES,A., 1974

El Ateneo de Madrid y la teoría de la Monarquía liberal (1836-1847), Madrid.

GIL DE ZÁRATE,A., 1842

"Don Manuel Bretón de los Herreros": N. Pastor Díaz y F. de Cárdenas, Galería de españoles célebres contemporáneos, Madrid, pp. 3-51.

GIL NOVALES,A., 1975

Las Sociedades Patrióticas (1820-1823). Las libertades de expresión y de reunión en el origen de los partidos políticos, Madrid.

GIL NOVALES,A., 1989 ( $2^{\text {a }}$ ed. $)$

El Trienio Liberal, Madrid.

JULIÁ, S., RINGROSE, D. y C. SEGURA, 1995

Madrid. Historia de una capital, Madrid.

LABRA, R. M. de, 1878

El Ateneo de Madrid. Sus orígenes, desenvolvimiento, representación y porvenir, Madrid.

LE GENTIL, G., 1909

Le poète Manuel Bretón de los Herreros et la societé espagnole de 1830 á 1860, París.

LONGARES, J., 1979

"La cruzada de la tinta. Los canales de difusdión de ideas en los comienzos del liberalismo español": Historia 16, Año IV, 35, pp. 120-125.

MARRAST, R., 1989

José de Espronceda y su tiempo, Barcelona.

MESONERO ROMANOS, R., [1975]

Memorias de un setentón, Madrid.

MURO, M.A., 1985

Ideas lingüísticas sobre el extranjerismo en Bretón de los Herreros, Logroño.

MURO, M.A., 1992

El teatro breve de Bretón de los Herreros, Logroño.

PÉREZ GARZÓN, J. S., 1978

Milicia Nacional y revolución burguesa. El prototipo madrileño, 1808-1874, Madrid.

PÉREZ GARZÓN, J. S., 1983

"El Eco del Comercio, portavoz del programa revolucionario de la burguesía española, 1832-1835": A. Gil Novales, ed., La prensa en la revolución liberal: España, Portugal y América Latina, Madrid, pp. 509-524. 
RINGROSE, D. R., 1986

"Ciudad, país y revolución burguesa: Madrid, del siglo XVIII al siglo XIX": L. E. Otero Carvajal y A. Bahamonde, eds., Madrid en la sociedad del siglo XIX, Vol. I, Madrid, pp. 301-323.

ROCA DE TOGORES, M., marqués de Molins, 1883

Bretón de los Herreros. Recuerdos de su vida y de sus obras, Madrid.

ROCA DE TOGORES, M., marqués de Molins, 1892

Bretón de los Herreros. Estudio crítico, Madrid.

SÁNCHEZ SALAS, B., 1990

Manuel Bretón de los Herreros y La Rioja: una relación tangencial, Logroño.

SEOANE, $\mathbf{M}^{\mathrm{a}} \mathrm{C} ., 1989$

Historia del periodismo en España. 2. El siglo XIX, Madrid.

TOMÁS VILLARROYA, J., 1965

"El cuerpo electoral en la ley de 1837": Revista del Instituto de Ciencias Sociales, 6, pp. 157-205.

TOMÁS VILLARROYA, J., 1981

"El proceso constitucional, 1834-1843": La era isabelina y el Sexenio Democrático (18341874), Tomo XXXIV de Historia de España dirigida por Menéndez Pidal, Madrid, pp. 5-67. 
